\title{
Effect of Alumina Additives on Mechanical and Fresh Properties of Self-Compacting Concrete: A Review
}

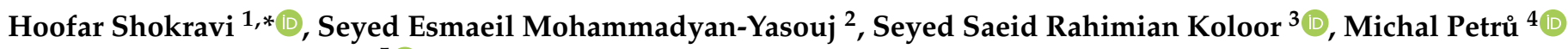 \\ and Mahshid Heidarrezaei ${ }^{5}$ (B) \\ 1 School of Civil Engineering, Faculty of Engineering, Universiti Teknologi Malaysia, \\ Skudai 81310, Johor, Malaysia \\ 2 Department of Civil Engineering, Najafabad Branch, Islamic Azad University, Najafabad 8514143131, Iran; \\ semy2016@pci.iaun.ac.ir \\ 3 Institute for Nanomaterials, Advanced Technologies, and Innovation (CXI), Technical University of \\ Liberec (TUL), Studentska 2, 46117 Liberec, Czech Republic; s.s.r.koloor@gmail.com \\ 4 Technical University of Liberec (TUL), Studentska 2, 46117 Liberec, Czech Republic; michal.petru@tul.cz \\ 5 School of Chemical \& Energy Engineering, Faculty of Engineering, Universiti Teknologi Malaysia, \\ Skudai 81310, Johor, Malaysia; mahshidheidarrezaei2@graduate.utm.my \\ * Correspondence: shokravihoofar@utm.my
}

check for

updates

Citation: Shokravi, H.;

Mohammadyan-Yasouj, S.E.; Koloor,

S.S.R.; Petrů, M.; Heidarrezaei, M.

Effect of Alumina Additives on

Mechanical and Fresh Properties of Self-Compacting Concrete: A Review.

Processes 2021, 9, 554. https://

doi.org/10.3390/pr9030554

Academic Editor:

Shaghayegh Hamzehlou

Received: 18 February 2021

Accepted: 15 March 2021

Published: 22 March 2021

Publisher's Note: MDPI stays neutral with regard to jurisdictional claims in published maps and institutional affiliations.

Copyright: (c) 2021 by the authors. Licensee MDPI, Basel, Switzerland. This article is an open access article distributed under the terms and conditions of the Creative Commons Attribution (CC BY) license (https:/ / creativecommons.org/licenses/by/ $4.0 /)$.

\begin{abstract}
Self-compacting concrete (SCC) has been increasingly used in the construction sector due to its favorable characteristics in improving various durability and rheology aspects of concrete such as deformability and segregation resistance. Recently, the studies on the application of nano-alumina (NA) produced from factory wastes have been significantly considered to enhancing the performance, and mechanical strength, of SCC. Many experimental works show that NA can be used in SCC with appropriate proportion to enjoy the benefits of improved microstructure, fresh and hardened properties, durability, and resistance to elevated temperature. However, a limited detailed review is available to particularly study using NA to improve the performance of SCC, so far. Hence, the present study is conducted to fill the existing gap of knowledge. In this study, the effect of using NA in improving rheological, mechanical parameters, and elevated temperature resistance of SCC is reviewed. This research summarized the studies in this area, which have been different from the previous researches, and provided a discussion on limitations, practical implications, and suggestions for future studies.
\end{abstract}

Keywords: self-compacting concrete; self-consolidating concrete; waste alumina; nano alumina; nanoparticles

\section{Introduction}

Concrete is a construction material that is widely used in buildings [1,2], bridges [3-5], and other civil structures [6,7]. The application of nanoparticles in concrete has received great attention recently because of the ultrafine size of their particles [8]. A limited number of nanoparticles have demonstrated utility for improving the durability and mechanical properties of concrete. Nazari and Riahi [9] reported that the addition of nano-alumina (NA) particles into concrete mixtures can enhance strength gaining, water permeability, and the pore structure characteristics of concrete. Khoshakhlagh et al. [10] indicated that the inclusion of $\mathrm{Fe}_{2} \mathrm{O}_{3}$ nanoparticles in cementitious materials improves the compressive strength. Moreover, $\mathrm{Fe}_{2} \mathrm{O}_{3}$ nanoparticles act as nanofillers to recover the pore structure enhancing the water permeability of concrete.

Self-compacting concrete (SCC) is concrete with enhanced fresh properties that allow pouring without external compaction [11,12]. SCC was first reported in Japan in 1988 [13]. SCC contains the same components as conventional concrete but with different proportions and fresh characteristics [14]. The main fresh characteristic of SCC is high workability that 
enables the concrete to fill formwork to achieve full compaction without vibration [15]. The compressive strength of SCC compared to the ordinary concrete with the same water to cement ratio is considerably higher [16]. The higher compressive strength of SCC is attributed to its dense microstructure as compared to conventional concrete [17]. Apart from high workability, SCC must possess a high filling ability, passing ability, and resistance to static and dynamic segregation [18]. Nazari and Riahi [19] indicated that the inclusion of $\mathrm{SiO}_{2}$ nanoparticles enhances the flexural strength of $\mathrm{SCC}$ and accelerates cement hydration. The inclusion of $\mathrm{TiO}_{2}$ nanoparticles also can improve the formation of C-S-H gel in SCC resulting in faster hydration and improved growth of the mechanical and durability properties of concrete [20-22].

NA is a chemical compound containing aluminum and oxygen $[23,24]$. The addition of NA to concrete can significantly affect the fresh properties of concrete due to their high ratio of surface area to volume [25]. NA has high chemical reactivity and behaves as pozzolanic reaction promoters owing to its high ratio of the surface area [26]. NA can improve the mechanical parameters of cementitious composites exposed to elevated temperatures [27]. It was reported that the inclusion of NA in SCC can accelerate the formation of hydrated products, and pore structure while reducing the workability of fresh concrete, water absorption of hardened specimens [28]. Table 1 shows the advantages and disadvantages of SCC which has been exploited from literature. As can be seen from the presented pros and cons analysis, the advantages are significantly higher than the inconveniences provoked. In Figure 1 ( $a$ and $b$ ) the application of roller alumina in tile manufacturing factories and the factory wastes of the alumina rollers are shown, respectively.

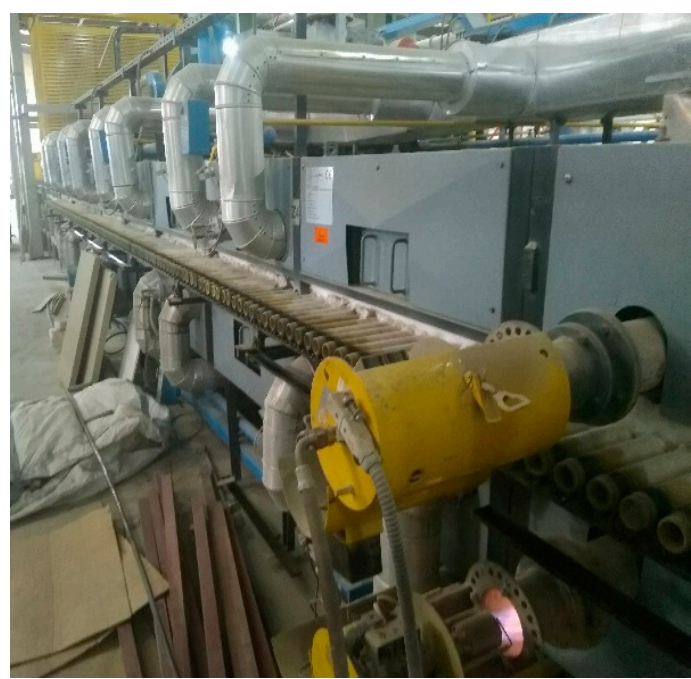

(a)

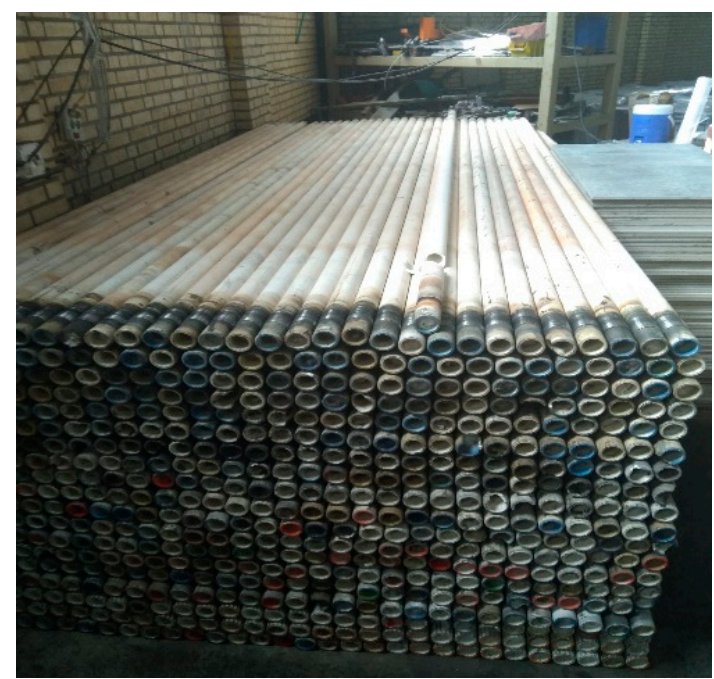

(b)

Figure 1. The application of roller alumina in tile manufacturing factories; (a) ceramic roller kiln, (b) factory wastes.

Since the introduction of SCC, a large number of studies are conducted on enhancing the engineering properties of the SCC as well as the prediction of the loading capacity of SCC based on the associated mixture design. Despite the large volume of literature on the production of SCC and the relevant admixtures such as nano-particles, little attention has been given to predicting the complex interaction between incorporated admixtures and mechanical characteristics of the SCC. To the authors' knowledge, there is no review paper on the prediction model for the compressive strength of SCC. Some papers have discussed the prediction of the mechanical and rhetorical behavior of SCC but their main focus is only on mixed design. This study attempts to fill part of this void in the literature by offering a discussion on the application of NA in SCC. 
Table 1. The advantages and disadvantages of self-compacting concrete (SCC).

\begin{tabular}{|c|c|c|c|}
\hline Advantages & Ref. & Disadvantages & Ref. \\
\hline $\begin{array}{l}\text { Speeded up } \\
\text { construction }\end{array}$ & [29] & Prolonged demolding time & [30] \\
\hline $\begin{array}{l}\text { Improved the } \\
\text { construction quality }\end{array}$ & {$[31]$} & $\begin{array}{l}\text { Increased risk and } \\
\text { associated uncertainty }\end{array}$ & [32] \\
\hline Safer work conditions & {$[33]$} & $\begin{array}{l}\text { Lowered elevated } \\
\text { temperature resistance }\end{array}$ & [34] \\
\hline $\begin{array}{l}\text { The increased service } \\
\text { life of formworks due } \\
\text { to the elimination } \\
\text { of vibration }\end{array}$ & {$[31]$} & $\begin{array}{l}\text { Higher formwork pressure } \\
\text { means higher } \\
\text { formwork costs. }\end{array}$ & [35] \\
\hline $\begin{array}{l}\text { Improved quality of } \\
\text { the final product }\end{array}$ & {$[33]$} & $\begin{array}{l}\text { Not fully known } \\
\text { fire behavior }\end{array}$ & [36] \\
\hline Reduced manpower & {$[33]$} & $\begin{array}{l}\text { Maintaining ready-mixed } \\
\text { is not easy under the } \\
\text { construction site }\end{array}$ & [37] \\
\hline $\begin{array}{l}\text { Improved ecological } \\
\text { footprint }\end{array}$ & {$[38]$} & $\begin{array}{l}\text { Not appropriate for every } \\
\text { application }\end{array}$ & [39] \\
\hline Improved economic & {$[38]$} & $\begin{array}{l}\text { Unsuitable choice for } \\
\text { horizontal castings }\end{array}$ & {$[40]$} \\
\hline $\begin{array}{l}\text { Enhanced filling } \\
\text { spaces in dense } \\
\text { reinforcement or } \\
\text { inaccessible voids }\end{array}$ & {$[38]$} & $\begin{array}{l}\text { Higher associated costs for } \\
\text { ready-mixed }\end{array}$ & {$[41]$} \\
\hline $\begin{array}{l}\text { Improved } \\
\text { freeze-thaw resistance }\end{array}$ & {$[42]$} & $\begin{array}{l}\text { Using conventional drum } \\
\text { mixers are not suitable for } \\
\text { the distribution }\end{array}$ & [43] \\
\hline $\begin{array}{l}\text { Noise-free working } \\
\text { atmosphere }\end{array}$ & {$[31]$} & $\begin{array}{l}\text { Not standardized } \\
\text { mix design }\end{array}$ & [44] \\
\hline
\end{tabular}

\section{Nanoparticles}

Nanotechnology has become a popular and necessary part of science and technology in recent years by addressing nanoparticles in atomic or molecular size [45]. Nanoparticles are defined as materials where at least one dimension of a particle is less than $100 \mathrm{~nm}$. Partial replacement of nano-materials with cement in the mix design can enhance the physical and chemical characteristics of fresh and hardened concrete [46]. The addition of nanoparticles can improve the microstructural properties, filler effect, compactness, and durability, as well as accelerating cement hydration [47]. Nanoparticles can also act as pozzolanic materials and produce the additional formation of calcium-silicate-hydrates $(\mathrm{C}-\mathrm{S}-\mathrm{H})$ gel and, by taking place of pozzolanic reactions. The $\mathrm{C}-\mathrm{S}-\mathrm{H}$ gel Formation can improve stiffness, flexural, tensile, and shear strength of cement-concrete [48]. Uniform dispersion of nanoparticles in concrete is the key issue in obtaining the expected mechanical and chemical characteristics $[49,50]$. The applied nanoparticles in the concrete mix to partially replace cement are spherical shapes cementitious materials.

The addition of nanoparticles can improve the microstructural properties, compactness, and durability of hardened concrete $[19,48]$. The effect of nanoparticles as partial cement replacement in the concrete mix has been studied by many researchers in recent years. Nano-SiO ${ }_{2}$ is the most widely investigated nanoparticle $[19,51-53]$ while the effect of adding other partials such as nano- $\mathrm{TiO}_{2}[22,54,55]$, nano- $\mathrm{Al}_{2} \mathrm{O}_{3}[9,56,57]$, nano- $\mathrm{ZnO}_{2}[58,59]$, nano- $\mathrm{Fe}_{2} \mathrm{O}_{3}[10,60]$, nano- $\mathrm{CuO}$ [61], nano-SnO $\mathrm{O}_{2}$, nano- $\mathrm{ZrO}_{2}$ [62], nano$\mathrm{TiO}_{2}$ [63], carbon nanotubes [64], carbon nano-fibers [45], polycarboxylates [65], nano$\mathrm{Cr}_{2} \mathrm{O}_{3}[48,66]$, nano-clay $[45]$ and nano- $\mathrm{CaCO}_{3}[62,67]$ in properties of fresh and hardened 
concrete has been investigated so far. For example, Tawfik et al. [68] evaluated the effect of nano-waste ceramic and nano-silica on the mechanical properties of hardened concrete. The obtained results showed improvement in the performance of concrete but also resolved the footprint caused by this waste. Jalal et al. [69] studied the effect of $\mathrm{TiO}_{2}$ nanoparticle inclusion in tensile strength, thermal, rheological, transport, and microstructural properties of SCC. The chemical effect of $\mathrm{TiO}_{2}$ as partial replacement of cement accelerates the formation of C-S-H gel and hydration resulting in increased split tensile strength of concrete specimens. Moreover adding $\mathrm{TiO}_{2}$ nanoparticles can enhance the pore structure of concrete by shifting the distributed pores into a less harmful configuration. Joshaghani et al. [20] evaluated the fresh, mechanical, and durability properties of nano- $\mathrm{TiO}_{2}$, nano- $\mathrm{Al}_{2} \mathrm{O}_{3}$ and nano- $\mathrm{Fe}_{2} \mathrm{O}_{3}$, on SCC two different contents of $3 \%$ and $5 \%$. It was observed that addition of $3 \%$ nanoparticles can slightly improve workability properties of the mixes by increasing the water demand. Calcium ferric hydrate (C-F-H) gel formation enhanced the compressive strength and durability properties in nano- $\mathrm{Fe}_{2} \mathrm{O}_{3}$, nano- $\mathrm{Al}_{2} \mathrm{O}_{3}$ and nano- $-\mathrm{TiO}_{2}$. It was reported that nanoparticles addition controlled the formation of C-S-H gel, lowering permeability to penetration of malicious ions of chloride.

Fresh properties of concrete containing nanoparticles are one of the most investigated subjects. Workability, flowability, and consistency of concrete are greatly affected by the addition of nanoparticles [70]. Generally, the flowability of SCC mixes is reduced by the addition of nanomaterials [71]. This reduction is mainly attributed to the ability of nanoparticles to absorb more water molecules due to their large area surface [20]. Mechanical properties of hardened concrete including flexural, tensile, shear, and compressive strength and their change due to incorporation of the microparticle in concrete are another most important study in recent years [72]. It is stated that nanoparticles act as nuclei to form hydration products filling micropores [73]. The formation of a dense C-S-H gel is facilitated by altering cement hydration that leads to an increase in compressive strength [74]. Adding excessive amounts of nanoparticles may adversely affect the compressive strength due to restricting the $\mathrm{Ca}(\mathrm{OH})_{2}$ crystals growth. Several research studies have investigated the influence of nanoparticles on the durability of hardened concrete. It was stated that the water absorption of SCC mixes with nanoparticles is different from the control specimens due to the formation of hydrated products [75]. On the other hand, the addition of nanoparticles may affect the capillary permeability of concrete and the specimens containing nanoparticles can better resist chloride penetration [76,77].

\section{Production Processes of Nano Alumina}

There are different methods for the extraction and production of alumina nanoparticles. Alumina is mainly extracted from two main resources of clays and coal fly ash (CFA) [78]. The row materials undergo several chemical processes for extracting their alumina contents. The production phase of nano alumina is performed by arc plasma, precipitation, hydrothermal, and sol-gel methods. Functionalization is the last step in NA production aiming at improving surface characteristics [79]. The functionalization process prevents agglomeration between alumina nano-particles that is mainly caused by the high surface energy and activity of nanoparticles [80,81].

\subsection{Extraction of Alumina Nanoparticles}

Clay is a natural mineral that is widely used to produce nano alumina due to its quite abundant availability and low cost. Kaoline is clay made from kaolinite $\mathrm{Al}_{2} \mathrm{O}_{3} \cdot 2 \mathrm{SiO}_{2} 2 \mathrm{H}_{2} \mathrm{O}$ that contains high alumina content ranged between 25 to $40 \%$. Kaolin is a product of weathering of all granitic rocks which is characterized by its fire resistance, good plasticity, and other unique chemical and physical properties [82]. Kaolin is a chemically inert material within a wide $\mathrm{pH}$ range and it is not listed as a hazardous material [83]. The alumina extraction process from clays is performed using acids such as nitric acid, hydrochloric, or sulfuric acid to dissolve the alumina followed by clay roasting. Heavy metal ores of clay 
are extracted using acid leachants [78]. The chemical reaction for removing heavy metals from clays can be shown below.

$$
\mathrm{Al}_{2} \mathrm{O}_{3} \mathrm{H}_{2} \mathrm{O}+3 \mathrm{H}_{2} \mathrm{SO}_{4} \rightarrow \mathrm{Al}_{2}\left(\mathrm{SO}_{4}\right)_{3}+4 \mathrm{H}_{2} \mathrm{O}
$$

CFA is another major source of alumina nanoparticles. CFA is rich in alumina and alumina contents in CFA is found around $50 \%$. The process of alumina extraction from CFA includes three important steps namely sintering [84], hydro-chemical [85], and acid processes [86]. The process of extracting alumina particles from CFA is shown in Figure 2.

\section{Sintering process}

Formation of soluble alumina compounds under high temperature to be treated with sodium carbonate

\begin{tabular}{c|}
\hline Hydro-chemical process \\
Alumina extraction \\
\hline Acid process \\
Reaction of acids to produce metal halide \\
\hline
\end{tabular}

Figure 2. The process of alumina extraction from coal fly ash (CFA).

\subsection{Production of Alumina Nanoparticles}

Different methods are developed to produce alumina nano-particles that include arc plasma, hydrothermal, sol-gel, and precipitation. The arc plasma process is defined as a thermal treatment of solid feedstock utilizing an arc between anode and cathode generally made of graphitic carbon for generating plasma. Using plasma for the production of alumina has lower residue as well as lower production and maintenance costs compared to traditional gas and oil burners [87]. Saravanakumar et al. [88] converted aluminum dross into ultrafine alumina powder using a plasma arc melting process. It was reported that the amount of the conversion of $\mathrm{Al}$ dross to alumina powder substantially correlates with plasma power. Madhu Kumar et al. [89] and Kumar et al. [90] used a D.C. arc plasma reactor for the preparation of alumina nano-particles. Fu et al. [91] adopted microwave oxygen plasma to prepare alumina nanoparticles sized 21-24 nm. Stanislaus et al. [92] investigated the hydrothermal process for the production of alumina nanoparticles in the presence and absence of various additives. Noguchi et al. [6] used hydrothermal reaction in supercritical water using a continuous flow reactor to prepare alumina -crystalline nano particles.

Sol-gel and coprecipitation, two common methods to extract nano alumina with different sizes and morphologies. spherical particles of alumina can be prepared by using the sol-gel method while spherical and hexagonal alumina particles can be formed by the co-precipitation method [93,94]. Mirjalili et al. [95] synthesized alumina nanoparticles by a sol-gel method. It was shown that the addition of surfactant and incorporated stirring time are parameters that affect the shape and size of the formed particle. Belekar et al. [96] obtained alumina granules with an average size of $30 \mathrm{~nm}$ by a modified sol-gel method. The process included hydrolysis of $\mathrm{Al}\left(\mathrm{NO}_{3}\right)_{3}$ in aqueous media. Esmaeilirad et al. [97] prepared alumina by heterogeneous deposition-precipitation, sol-gel, and the co-precipitation methods. The alumina prepared by the sol-gel method using La-Cu/AISE showed the best 
performance. Feng et al. [98] used aluminum powders as the aluminum source and acetic acid as precipitants to prepare alumina powders in a precipitation process.

\section{Sustainability of Nano Alumina}

The use of nanoparticles is not yet a cost-effective option for the construction industry and particularly as a concrete additive. Hence, meaningful approaches are needed to be carried out to overcome that limitation. The valorization of industrial waste is a sustainable way to wisely utilize renewable resources. Aluminum dross is a toxic industrial waste generated from aluminum refining industries that contain aluminum oxynitride $(\mathrm{AlON})$, aluminum oxide $\left(\mathrm{Al}_{2} \mathrm{O}_{3}\right)$, aluminum metal $(\mathrm{Al})$, and impurities such as potassium chloride and sodium chloride [88]. Based on reports nearly $95 \%$ of aluminum dross is landfilled without treatment that is hazardous to the environment in China [99]. Using conventional disposal or landfilling practices of aluminum wastes without proper treatment and recycling strategy can adversely contribute to human health due to the toxic nature of materials [100]. Hence aluminum dross should be converted into inert or less toxic products [88].

EI-Katatny et al. [101] used caustic soda for leaching an aluminum factory waste under atmospheric and high-pressure aluminum to form alumina. David and Kopac [102] proposed an alumina extraction method from aluminum dross using a chemical route. Dash et al. [103] recycled aluminum dross using acid dissolution and salt treatment for recovering residual aluminum. Das et al. [104] adopted acid treatment for the recycling of aluminum dross to obtain alumina generated by Indian aluminum industries. Sarker et al. [105] used an acid dissolution process to extract alumina from Bangladesh foundry industries. Singh et al. [106] optimized a chemical process for the production of alumina through recycling aluminum dross. How et al. [107] recovered alumina from the wastes of an aluminum production factory in Malaysia. The recovering process of alumina consisted of acid leaching, alkaline precipitation, and calcinations steps. Most of the aforementioned processes incorporated alkaline salts for the treatment of aluminum dross that are hazardous to groundwater and agricultural soil and it is important to remove these chemicals before discharging them to the environment.

Plasma processing of materials is a fast and environmentally-friendly method to treat and high volume reduction of various types of wastes. Szente et al. [87] conducted a comparative study on using plasma systems and traditional oil and gas burners for recovering aluminum from dross. It was reported that the plasma process provides cheaper operation costs (at least 23\%) with lower residues than oil/gas burners. Yang et al. [108] treated aluminum dross using a radio frequency-based plasma to recover high-purity fine aluminum oxide (with the size of $8 \mu \mathrm{m}$ ). Saravanakumar et al. [88] reported using arc plasma to convert dross of aluminum into alumina powder in an eco-friendly manner. The obtained results indicated that the application of arc plasma can be efficiently used to treat aluminum dross to recover alumina powder.

\section{Self-Compacting Concrete (SCC)}

SCC mixes always contain a large number of powder materials, viscosity-modifying admixtures, and superplasticizer [109-111]. Higher cement content in concrete has some negative effects such as a rise in material cost, increased thermal stress, and shrinkage [112]. The requirement for cement replacements in SCC is usually met by the use of filler materials such as fly ash (FA), pulverized fuel ash (PFA), marble powder (MP), basalt powder (BP), granulated ground blast-furnace slag (GGBS), limestone powder, etc. [112]. Uysal and Sumer [113] investigated the effect of different mineral admixtures on the properties of SCC such as durability, workability, and reducing cement content. The replacement of Portland cement with FA, GGBS, BP, and MP increases the fluidity and can improve mechanical properties, and durability of the SCC against sulfate attack. Fathi et al. [114] also testified that fibers reduce the slump and compressive strength of SCC but increase its flexural tensile strength. Talking about mechanical properties, Ahmad et al. [115] compared the 
mechanical properties of normal concrete (NC), SCC, and glass fiber reinforced SCC. It was observed that addition of fiber glass to SCC decreased the workability of the concrete but it significantly enhanced flexural of ruptures in test specimens. The change in compressive strength by addition of glass fibers was small enough to be ignorable.

SCC is extensively used in various types of structures such as commercial buildings and industrial structures that are subjected to high temperatures or accidental fires. Hence, gaining proper information on the effects of high temperatures on the performance of SCC is necessary. The effect of high-temperature on the behavior of SCC was studied by many researchers. Anand et al. [116] reviewed the effect of the elevated temperature on the chemical and mechanical properties of concrete. Distinct behavior was found in mechanical properties of normal, high strength, and SCC when they are exposed to high temperatures. It was revealed that parameters such as the compressive, tensile, and flexural strength of concrete, water-cement ratio, cement type, the density of concrete, aggregate type, reinforcement percentage, and reinforcement cover are some of the important factors that affect the concrete performance at elevated temperature.

Annerel et al. [117] revealed that the thermal influence of raised temperature on the mechanical behavior of SCC is much significant compared to normal concrete. Pineaud et al. [118] studied the mechanical properties of high-performance SCC under raised temperatures ranged from 20 to $600{ }^{\circ} \mathrm{C}$. The results of experiments on 11 different mix designs showed that increasing the temperature reduces their E-value and compressive strength significantly. Andiç-Çakır and Hizal [119] explored the properties of SCC under raised temperature ranged from 300 to $900{ }^{\circ} \mathrm{C}$. It was shown that the aggregate type and w/c ratio are the most influential parameters in the modulus of elasticity and compressive strength of the SCC while the aggregate type is the main influential parameter in tensile strength. Table 2 shows some of these changes within a various temperature range of exposure. Further studies on the influence of raised temperature on the mechanical properties of concrete can be found somewhere else [120-122]. There are limited studies on the behavior of SCC with nanoparticles and subjected to high-temperature $[123,124]$.

Table 2. The changes in physical and chemical parameters of concrete due to exposure to elevated temperature (data are exploited from [120]).

\begin{tabular}{|c|c|c|}
\hline Investigated Parameter & Temperature Range & Effect of Temperature Rise \\
\hline Compressive strength & $100-800{ }^{\circ} \mathrm{C}$. & - Decreases in a linear rate \\
\hline Porosity and pore size & $\begin{array}{l}100-800{ }^{\circ} \mathrm{C} . \\
\text { Above } 1000{ }^{\circ} \mathrm{C} \text {, }\end{array}$ & $\begin{array}{l}\text { - Increase of porosity and } \\
\text { pore sizes } \\
\text { - } \quad \text { Porosities are smaller } \\
\text { and better structured }\end{array}$ \\
\hline Elastic modulus. & $100-800{ }^{\circ} \mathrm{C}$. & - Decreases in a linear rate \\
\hline Splitting tensile strength & $100-800{ }^{\circ} \mathrm{C}$ & - Decreases in a linear rate \\
\hline Stress-strain relationship & $100-800{ }^{\circ} \mathrm{C}$ & $\begin{array}{l}\text { Flatter stress-strain } \\
\text { curves, downwards and } \\
\text { rightwards shift of the } \\
\text { peak stress }\end{array}$ \\
\hline Residual flexural strength & $100-800{ }^{\circ} \mathrm{C}$ & - Decreases in a linear rate \\
\hline Water evaporation & $\begin{array}{l}\text { At } 105^{\circ} \mathrm{C} \\
\text { At } 400^{\circ} \mathrm{C}\end{array}$ & $\begin{array}{l}\text { - Free water and } \\
\text { physically absorbed } \\
\text { water are completely lost. } \\
\text { Chemically bonded } \\
\text { water start to lose } \\
\text { Capillary water is lost } \\
\text { completely }\end{array}$ \\
\hline
\end{tabular}


Table 2. Cont.

\begin{tabular}{lcl}
\hline \multicolumn{1}{c}{ Investigated Parameter } & Temperature Range & Effect of Temperature Rise \\
\hline Hydration & Up to $300^{\circ} \mathrm{C}$ & $\begin{array}{l}\text { Hydration of } \\
\text { un-hydrated cement is } \\
\text { improved }\end{array}$ \\
\hline Microstructure & $\begin{array}{l}\mathrm{Up} \text { to } 200{ }^{\circ} \mathrm{C} \\
200{ }^{\circ} \mathrm{C}-400^{\circ} \mathrm{C}\end{array}$ & $\begin{array}{l}\text { No micro-cracks } \\
\text { The intensity of } \\
\text { micro-cracks increases }\end{array}$ \\
\hline
\end{tabular}

\section{Nano Alumina (NA) Applications in SCC}

Nanotechnology is a research area that has revolutionized the mechanical and chemical properties of materials $[125,126]$. Nanotechnology is a promising research field with applications to improve the quality of the product and the performance of concretes [127]. The nanoparticle is applied in SCC aiming to reduce segregation and to modify fresh properties and mechanical strength., and. NA is a kind of ultra-fine chemical compound of aluminum and oxygen with a large surface area, high density, high melting point, high hardness, and good chemical stability with particle sizes in the range of 1 100 nm [128]. The advantages of using NA in concrete are presented in Table 3.

Table 3. Advantages of using nano-alumina (NA) in concrete.

\begin{tabular}{lc}
\hline \multicolumn{1}{c}{ Advantages } & Reference \\
\hline Reduced porosity of the microstructure as the voids were filled by NS. & {$[129]$} \\
\hline Decreased in water absorption & {$[130]$} \\
\hline Improved frost resistance of concrete & {$[131]$} \\
\hline $\begin{array}{l}\text { Controlled the setting time of the cement through a faster hydration } \\
\text { process will be. }\end{array}$ & {$[132]$} \\
\hline Reduced amount of un-hydrated cement in the mix & {$[129]$} \\
\hline Increased modulus of elasticity of cement mortar. & {$[133]$} \\
\hline Reduced segregation and flocculation. & {$[124]$} \\
\hline Refined voids in the hydration gel as a nanofiller. & {$[124]$} \\
\hline Reduced coefficients of permeability by 1-3 orders of magnitude. & {$[133]$} \\
\hline
\end{tabular}

Sua-iam et al. [134] studied the effect of using recycled NA and fly ash in SCC. It was shown that using recycled NA and fly ash could considerably enhance the compressive strength and workability of SCC. Mohseni et al. studied the effects of NA and rice husk ash (RHA) in polypropylene fiber (PPF) reinforced concrete. The combined inclusion of, $\mathrm{NA}, \mathrm{PPF}$, and RHA reduced the water absorption and drying shrinkage of mortars and increased flexural strength. Farzadnia et al. [135] investigated the chemical composition, microstructure and mechanical properties of NA-based high strength mortars subjected to elevated temperatures ranged from $100{ }^{\circ} \mathrm{C}$ to $1000{ }^{\circ} \mathrm{C}$. It was indicated that the addition of NA improved $16 \%$ of the compressive strength of samples. Behfarnia and Salemi [136] studied the influence of NS and NA on frost resistance and mechanical properties of concrete. Higher frost-resistance was achieved for concrete with NA while concrete containing NS had higher compressive strength. Zhan et al. [137] analyzed the effect of NA in the hydration of cement. Accelerated cement hydration and enhanced compressive strength at all ages were recorded. Owing to accelerated cement hydration, the strongest growth at 28 days was less obvious. Mohammadyan-Yasouj et al. [27] investigated the compressive strength and modulus of elasticity of each SCC mix design under temperatures of $27^{\circ} \mathrm{C}$, $100{ }^{\circ} \mathrm{C}, 200{ }^{\circ} \mathrm{C}, 300^{\circ} \mathrm{C}, 450{ }^{\circ} \mathrm{C}$, and $600^{\circ} \mathrm{C}$ for specimens cured in 7 and 28 -days. It was observed that addition of NA into the mix enhances the compressive strength of SCC for 
samples cured at 28 -day in temperature under $100{ }^{\circ} \mathrm{C}$. E-value of the samples cured on 28-day exhibited increasing trend. Figure 3 shows the comparison compressive strength of self-compacting concrete (SCC) at target temperatures for specimens cured at 28-days.

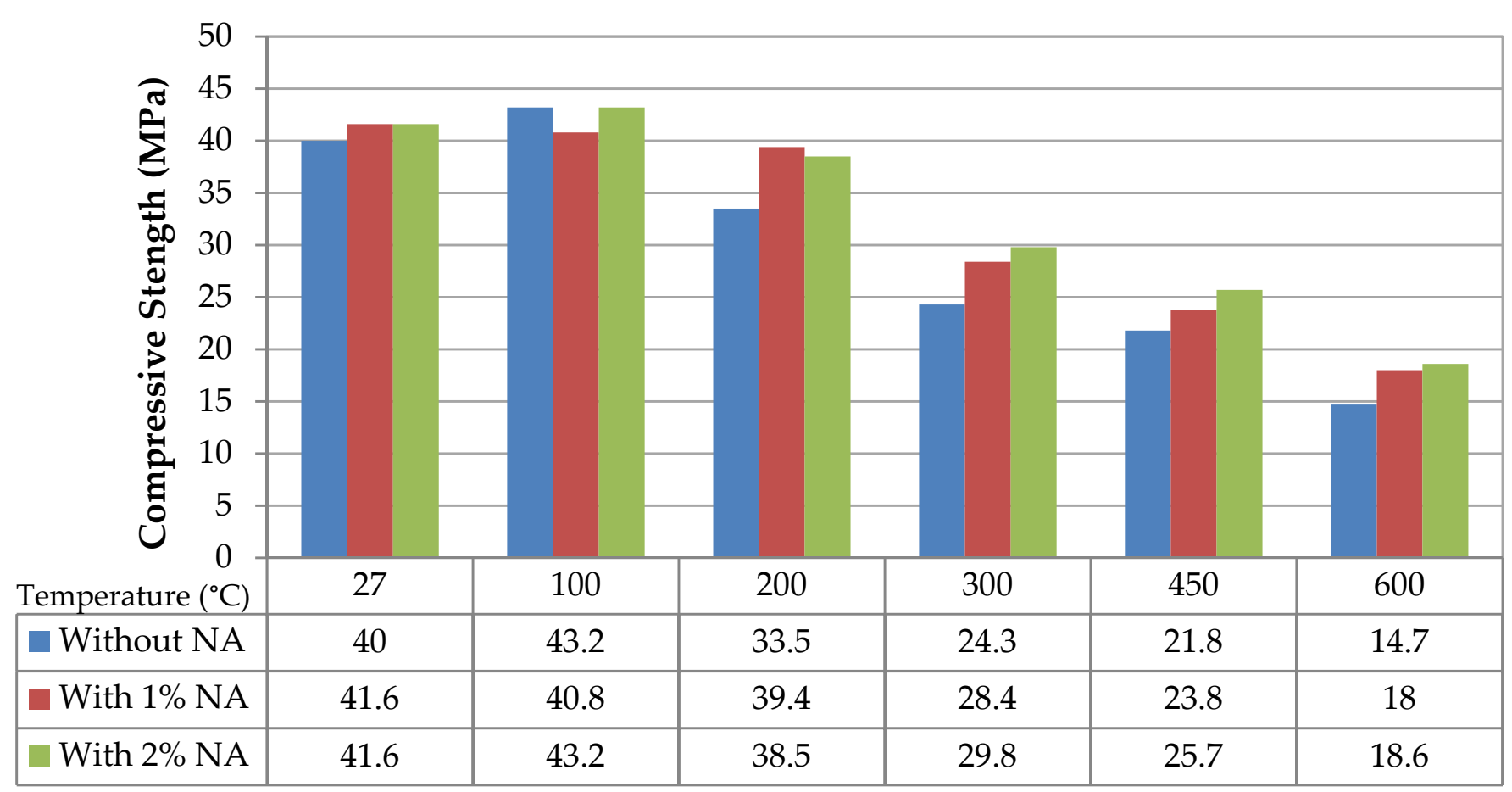

Figure 3. Comparison of 28-day compressive strength of self-compacting concrete (SCC) at target temperatures [27].

Szymanowski and Sadowski [138] explored the applicability of NA mortars for overlaying concrete floors. It was shown that the mortar with $\mathrm{Al}_{2} \mathrm{O}_{3}$ nano-powder used to make the overlay was less porous than the reference mortar. Li et al. [139] investigated the effect of NA on the elastic modulus of cement composite. Based on the experiment, the elastic modulus of mortars was increased by incorporating NA into the matrix. Nazari and Riahi [9] investigated the effect of curing medium on the physical, mechanical, and thermal properties of NA concrete. It was observed that curing of the specimens in saturated limewater resulted in accelerated setting time. Barbhuiya et al. [140] reported the effects of NA inclusion on the early-age microstructural properties of cement paste. It was revealed a denser microstructure with larger crystals of portlandite in the cement matrix. Mohseni et al. [77] conducted a comparative study on the single and the combined effects of adding NS), nano alumina (NA), and NT on the durability and mechanical properties of SCC. The ternary combination of NA, NS, and NT had the best permeability to chloride ingress and electrical resistivity at 3\%. Heikal et al. [141] studied the resistance of cement pastes with NA against fire. By enhancing the hydration reaction of cement phases higher compressive strength, bulk density, gel/space ratio was reported for the prepared cement paste. Khaliq and Khan [121] investigated the material properties of calcium aluminate cement concrete (CACC) under elevated temperatures. It was revealed that the presence of alumina as a binding agent significantly enhances the mechanical performance and axial strain in CACC. Niewiadomski et al. [42] presented a comparative study to assess the effect of NA, NS, and NT nanoparticle additives. It was indicated that the addition of up to 4 wt.\% of NA and NT showed no improvement in concrete strength. Table 4 summarizes the literature on the application of NA in SCC. 
Table 4. Summary of the literature on the application of nano-alumina (NA) in SCC.

\begin{tabular}{|c|c|c|c|c|c|c|c|c|c|}
\hline \multirow[b]{2}{*}{ Ref. } & \multirow[b]{2}{*}{ Research Topic } & \multirow{2}{*}{$\begin{array}{c}\text { Test Age } \\
\text { (day) }\end{array}$} & \multirow[b]{2}{*}{ Sample Size } & \multirow[b]{2}{*}{ W/C (\%) } & \multicolumn{4}{|c|}{ Alumina } & \multirow[b]{2}{*}{ Remarks } \\
\hline & & & & & Type & Size (mm) & $\begin{array}{l}\text { Amount of } \\
\text { Alumina }\end{array}$ & $\begin{array}{l}\text { Investigated } \\
\text { Parameters }\end{array}$ & \\
\hline $\begin{array}{c}\text { Suaiam and } \\
\text { Makul }[134,142]\end{array}$ & $\begin{array}{c}\text { Rheological and } \\
\text { mechanical } \\
\text { properties SCC } \\
\text { with high } \\
\text { volumes of } \\
\text { alumina }\end{array}$ & $\begin{array}{l}28 \text { and } \\
90 \text { days }\end{array}$ & $\begin{array}{c}\Phi 150 \mathrm{~mm} \times \\
300 \mathrm{~mm}\end{array}$ & 0.38 & Alumina & Below $\approx 5 \mathrm{~mm}$ & $\begin{array}{c}0,25,50,75, \text { and } \\
100 \% \text { of the total } \\
\text { fine aggregate }\end{array}$ & $\begin{array}{ll}\text { - } & \text { Velocity } \\
& \text { measurements } \\
\text { - } & \text { Compressive } \\
& \text { strength, } \\
\text { - } & \text { V-funnel, } \\
\text { - } & \text { Blocking flow } \\
& \text { assessment } \\
\text { - } & \text { J-ring flow } \\
\text { - } & \text { Ultrasonic pulse } \\
\text { - } & \text { Slump flow, }\end{array}$ & $\begin{array}{l}\text { - SCC mixtures } \\
\text { containing waste } \\
\text { alumina had } 75 \% \\
\text { higher } \\
\text { compressive } \\
\text { strength. }\end{array}$ \\
\hline $\begin{array}{l}\text { Mohseni et al. } \\
\text { [143] }\end{array}$ & $\begin{array}{l}\text { Cement mortars } \\
\text { containing rice } \\
\text { husk ash, } \\
\text { Polypropylene } \\
\text { fiber (PPF), and } \\
\text { nano-alumina } \\
\text { (NA) }\end{array}$ & $\begin{array}{l}28 \text { and } \\
90 \text { days }\end{array}$ & $\begin{array}{c}50 \times 50 \times \\
50 \mathrm{~mm}^{3} \text { and } \\
50 \times 50 \times \\
200 \mathrm{~mm}^{3}\end{array}$ & 0.49 & NA & $20 \mathrm{~nm}$ & $0,1,2$ and $3 \%$ & $\begin{array}{ll}\text { - } & \text { Compressive } \\
\text { strength, } \\
\text { - } \quad \text { Flexural } \\
\text { strength, } \\
\text { - Water } \\
\text { absorption and } \\
\text { - } \begin{array}{l}\text { Drying } \\
\text { shrinkage }\end{array}\end{array}$ & $\begin{array}{l}\text { - NA improved the } \\
\text { compressive } \\
\text { strength of mortar } \\
\text { The addition of } \\
\text { RHA, NA, and } \\
\text { PPF reduced both } \\
\text { drying shrinkage } \\
\text { and water } \\
\text { absorption and } \\
\text { increased flexural } \\
\text { strength. }\end{array}$ \\
\hline $\begin{array}{c}\text { Gowda et al. } \\
\text { [129] }\end{array}$ & $\begin{array}{c}\text { Durability and } \\
\text { microstructural } \\
\text { properties of } \\
\text { mortars with } \\
\text { NA }\end{array}$ & 28 days & $\begin{array}{c}70.5 \times 70.5 \times \\
70.5 \mathrm{~mm}^{3}\end{array}$ & 0.79 & NA & - & 1,3 and $5 \%$ & $\begin{array}{ll}\text { - } & \text { Water } \\
\text { - } & \text { absorption } \\
\text { Electrical } \\
\text { resistivity } \\
\text { - Scanning } \\
\text { electron } \\
\text { microscope } \\
\text { (SEM) }\end{array}$ & $\begin{array}{l}\text { Increasing of the } \\
\text { NA increased } \\
\text { water absorption } \\
\text { Electrical resistivity } \\
\text { was almost the } \\
\text { same for 3\% and } \\
\text { 5\% NA. } \\
\text { The addition of NA } \\
\text { gave a denser } \\
\text { microstructure in } \\
\text { the mortar. }\end{array}$ \\
\hline
\end{tabular}


Table 4. Cont

\begin{tabular}{|c|c|c|c|c|c|c|c|c|c|}
\hline \multirow[b]{2}{*}{ Ref. } & \multirow[b]{2}{*}{ Research Topic } & \multirow{2}{*}{$\begin{array}{l}\text { Test Age } \\
\text { (day) }\end{array}$} & \multirow[b]{2}{*}{ Sample Size } & \multirow[b]{2}{*}{ W/C (\%) } & \multicolumn{4}{|c|}{ Alumina } & \multirow[b]{2}{*}{ Remarks } \\
\hline & & & & & Type & Size (mm) & $\begin{array}{l}\text { Amount of } \\
\text { Alumina }\end{array}$ & $\begin{array}{l}\text { Investigated } \\
\text { Parameters }\end{array}$ & \\
\hline $\begin{array}{c}\text { Farzadnia et al. } \\
{[135]}\end{array}$ & $\begin{array}{c}\text { Elevated } \\
\text { temperature's } \\
\text { effect on NA } \\
\text {-based mortars }\end{array}$ & $\begin{array}{l}1,7 \text {, and } \\
28 \text { days }\end{array}$ & $\begin{array}{c}50 \times 50 \\
\times 50 \mathrm{~mm}^{3} \\
\text { and } \Phi 20 \mathrm{~mm} \\
\times 50 \mathrm{~mm}\end{array}$ & 0.35 & NA & $\begin{array}{l}\text { the average size of } \\
13 \mathrm{~nm}\end{array}$ & $0,1,2$ and $3 \%$ & $\begin{array}{ll}\text { - } & \text { Differential } \\
\text { scanning } \\
\text { calorimetry } \\
\text { (DSC) } \\
\text { - } \quad \text { X-ray powder } \\
\text { diffractometry } \\
\text { (XRD) } \\
\text { - } \quad \text { SEM tests } \\
\text { - } \quad \text { Residual } \\
\text { compressive } \\
\text { strength, } \\
\text { Elastic modulus, } \\
\text { and } \\
\text { Measurement of } \\
\text { gas permeability } \\
\text { coefficient }\end{array}$ & $\begin{array}{l}\text { - NA enhanced the } \\
\text { compressive } \\
\text { strength of } \\
\text { mortars by } 16 \% \text {. } \\
\text { NA improved } \\
\text { residual properties } \\
\text { of mortars at } \\
\text { temperatures from } \\
0^{\circ} \mathrm{C} \text { to } 400^{\circ} \mathrm{C} \text {. } \\
\text { The addition of } 1 \% \\
\text { NA reduced gas } \\
\text { permeability of } \\
\text { mortars at } \\
\text { temperatures from } \\
0{ }^{\circ} \mathrm{C} \text { to } 600{ }^{\circ} \mathrm{C} \text {. } \\
\text { The inclusion of } \\
\text { NA reduced the } \\
\text { intensity of } \mathrm{CH} \\
\text { formation at room } \\
\text { temperature and } \\
400{ }^{\circ} \mathrm{C} \text {. } \\
\text { The NA inclusion } \\
\text { transformed the } \\
\mathrm{CH} \text { crystallization } \\
\text { from well to ill. }\end{array}$ \\
\hline $\begin{array}{l}\text { Behfarnia and } \\
\text { Salemi [136] }\end{array}$ & $\begin{array}{l}\text { Frost resistance } \\
\text { of NA concrete }\end{array}$ & $\begin{array}{l}7,28 \text { and } \\
120 \text { days }\end{array}$ & $\begin{array}{l}70 \times 70 \times \\
70 \mathrm{~mm}^{3}\end{array}$ & 0.48 & NA & $15 \mathrm{~nm}$ & $\begin{array}{c}1 \% \text { and more } \\
\text { than } 2 \%\end{array}$ & $\begin{array}{ll}\text { - } & \text { Compressive } \\
\text { strength } \\
\text { - } \\
\text { Loss of mass } \\
\text { measurement } \\
\text { - } \text { Change in } \\
\text { length } \\
\text { - Water } \\
\text { absorption test }\end{array}$ & $\begin{array}{l}\text { - NA increased the } \\
\text { compressive } \\
\text { strength of } \\
\text { concrete. } \\
\text { Frost resistance of } \\
\text { concrete mixes } \\
\text { improved by the } \\
\text { addition of NA. }\end{array}$ \\
\hline
\end{tabular}


Table 4. Cont.

\begin{tabular}{|c|c|c|c|c|c|c|c|c|c|}
\hline \multirow[b]{2}{*}{ Ref. } & \multirow[b]{2}{*}{ Research Topic } & \multirow[b]{2}{*}{$\begin{array}{l}\text { Test Age } \\
\text { (day) }\end{array}$} & \multirow[b]{2}{*}{ Sample Size } & \multirow[b]{2}{*}{ W/C (\%) } & \multicolumn{4}{|c|}{ Alumina } & \multirow[b]{2}{*}{ Remarks } \\
\hline & & & & & Type & Size (mm) & $\begin{array}{l}\text { Amount of } \\
\text { Alumina }\end{array}$ & $\begin{array}{c}\text { Investigated } \\
\text { Parameters }\end{array}$ & \\
\hline Zhan et al. [137] & $\begin{array}{l}\text { Effect of NA on } \\
\text { early hydration } \\
\text { and mechanical } \\
\text { properties of } \\
\text { cement pastes }\end{array}$ & $\begin{array}{c}1,3,7 \text {, and } \\
28 \text { days }\end{array}$ & $\begin{array}{l}\text { cubes of size } \\
20 \mathrm{~mm} \times \\
20 \mathrm{~mm} \times \\
20 \mathrm{~mm} \\
\text { cubes of size } \\
6 \mathrm{~mm} \times \\
6 \mathrm{~mm} \times \\
13 \mathrm{~mm}\end{array}$ & 0.456 & NA & $30 \mathrm{~nm}$ & $\begin{array}{c}0 \%, 1 \%, 2 \% \text { and } \\
4 \%\end{array}$ & $\begin{array}{ll}\text { - } & \text { Compressive } \\
\text { strength } \\
\text { - } \\
\text { Isothermal } \\
\text { conduction } \\
\text { calorimetry } \\
\text { - } \quad \text { Thermogravimetric } \\
\text { analysis } \\
\text { Backscattered } \\
\text { electron imaging } \\
\text { and energy } \\
\text { dispersive } \\
\text { spectroscopy } \\
\text { Mercury } \\
\text { intrusion } \\
\text { porosimetry } \\
\text { (MIP) }\end{array}$ & 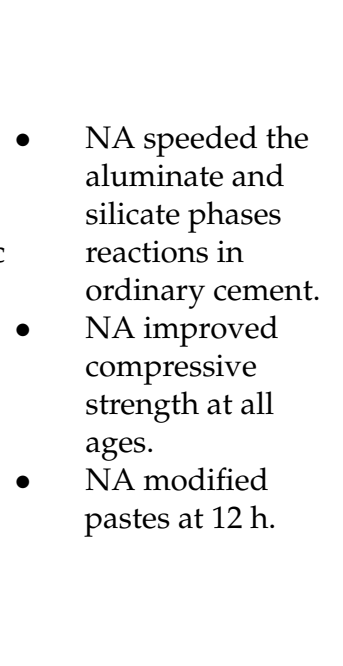 \\
\hline $\begin{array}{c}\text { Szymanowski } \\
\text { and Sadowski } \\
{[138]}\end{array}$ & $\begin{array}{l}\text { NA-based } \\
\text { cement mortars } \\
\text { for concrete } \\
\text { floors }\end{array}$ & 28 days & $\begin{array}{c}71 \times 71 \times \\
71 \mathrm{~mm}^{3} \\
11 \times 11 \times \\
11 \mathrm{~mm}^{3} \\
\text { and } 40 \times 40 \\
\times 80 \mathrm{~mm}^{3}\end{array}$ & 0.3 & NA & Below $50 \mathrm{~nm}$ & $0.5,1$ and $1.5 \%$ & 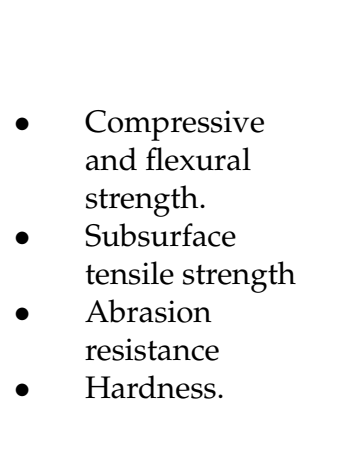 & $\begin{array}{l}\text { - The addition of } \\
0.5 \% \text { of NA } \\
\text { increased } \\
\text { subsurface tensile } \\
\text { strength and } \\
\text { reduced abrasion } \\
\text { resistance } \\
\text { The addition of } \\
0.5 \% \text { of NA } \\
\text { resulted in a less } \\
\text { porous mortar } \\
\text { than the reference. }\end{array}$ \\
\hline
\end{tabular}


Table 4. Cont.

\begin{tabular}{|c|c|c|c|c|c|c|c|c|c|}
\hline \multirow[b]{2}{*}{ Ref. } & \multirow[b]{2}{*}{ Research Topic } & \multirow[b]{2}{*}{$\begin{array}{c}\text { Test Age } \\
\text { (day) }\end{array}$} & \multirow[b]{2}{*}{ Sample Size } & \multirow[b]{2}{*}{$\mathrm{W} / \mathrm{C}(\%)$} & \multicolumn{4}{|c|}{ Alumina } & \multirow[b]{2}{*}{ Remarks } \\
\hline & & & & & Type & Size $(\mathrm{mm})$ & $\begin{array}{l}\text { Amount of } \\
\text { Alumina }\end{array}$ & $\begin{array}{l}\text { Investigated } \\
\text { Parameters }\end{array}$ & \\
\hline Li et al. [139] & $\begin{array}{l}\text { Preparation and } \\
\text { mechanical } \\
\text { properties of the } \\
\text { NA based } \\
\text { cement } \\
\text { composite }\end{array}$ & $\begin{array}{l}3 \text { days, } \\
7 \text { days, } \\
28 \text { days }\end{array}$ & $\begin{array}{l}\Phi 20 \times \\
40 \mathrm{~mm}\end{array}$ & 0.4 & NA & Below $150 \mathrm{~nm}$ & $5 \%$ and $7 \%$ & $\begin{array}{ll}\text { - } & \text { Elastic modulus } \\
\text { - } & \text { Compressive } \\
\text { strength }\end{array}$ & $\begin{array}{l}\text { - In } 5 \% \text { of NA, the } \\
\text { E-value of } \\
\text { composites } \\
\text { improved by } \\
143 \% \text {. } \\
\text { The compressive } \\
\text { strength of } 5 \% \text { NA } \\
\text { composites } \\
\text { increased by } 30 \% \\
\text { at } 7 \text { days. }\end{array}$ \\
\hline $\begin{array}{c}\text { Nazari and } \\
\text { Riahi [9] }\end{array}$ & $\begin{array}{l}\text { Different curing } \\
\text { media for NA in } \\
\text { concrete }\end{array}$ & $\begin{array}{c}7,28 \text { and } \\
90 \text { days }\end{array}$ & $\begin{array}{l}\text { Cubes of } \\
100 \mathrm{~mm} \\
\text { edge for } \\
\text { compressive } \\
\text { strength } \\
\text { tests, cubes } \\
\text { with } 200 \mathrm{~mm} \\
\times 50 \mathrm{~mm} \times \\
50 \mathrm{~mm}\end{array}$ & 0.40 & NA & $15 \mathrm{~nm}$ & $\begin{array}{c}0.5 \%, 1.5 \% \text { and } \\
2 \%\end{array}$ & $\begin{array}{l}\text { - } \quad \begin{array}{l}\text { Compressive } \\
\text { strength }\end{array} \\
\text { water absorption } \\
\text { - } \quad \text { XRD analysis } \\
\text { Split tensile strength } \\
\text { Flexural strength } \\
\text { - } \\
\text { Thermogravimetric } \\
\text { analyzer (TGA) }\end{array}$ & 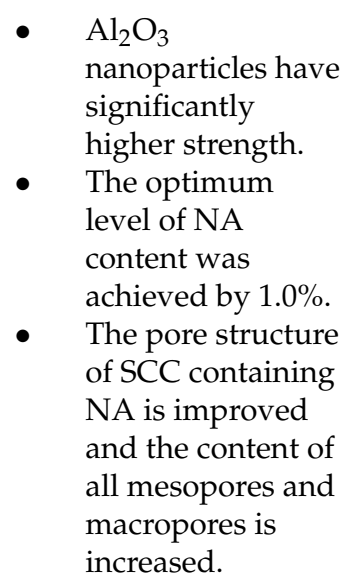 \\
\hline
\end{tabular}


Table 4. Cont.

\begin{tabular}{|c|c|c|c|c|c|c|c|c|c|}
\hline \multirow[b]{2}{*}{ Ref. } & \multirow[b]{2}{*}{ Research Topic } & \multirow[b]{2}{*}{$\begin{array}{l}\text { Test Age } \\
\text { (day) }\end{array}$} & \multirow[b]{2}{*}{ Sample Size } & \multirow[b]{2}{*}{ W/C (\%) } & \multicolumn{4}{|c|}{ Alumina } & \multirow[b]{2}{*}{ Remarks } \\
\hline & & & & & Type & Size (mm) & $\begin{array}{c}\text { Amount of } \\
\text { Alumina }\end{array}$ & $\begin{array}{c}\text { Investigated } \\
\text { Parameters }\end{array}$ & \\
\hline $\begin{array}{c}\text { Barbhuiya et al. } \\
\text { [140] }\end{array}$ & $\begin{array}{c}\text { Early-age } \\
\text { microstructural } \\
\text { properties of } \\
\text { adding NA to } \\
\text { cement paste }\end{array}$ & $\begin{array}{c}1,3,7 \text {, and } \\
28 \text { days }\end{array}$ & $\begin{array}{c}50 \times 50 \times \\
50 \mathrm{~mm}^{3}\end{array}$ & 0.40 & NA & $27-43 \mathrm{~nm}$ & $2 \%$ and $4 \%$ & $\begin{array}{l}\text { - } \quad \text { Compressive } \\
\text { strength } \\
\text { water absorption } \\
\text { - } \quad \text { XRD analysis } \\
\text { - } \quad \text { FTIR analysis } \\
\text { - } \quad \text { Electron } \\
\text { microscopy } \\
\text { Scanning }\end{array}$ & 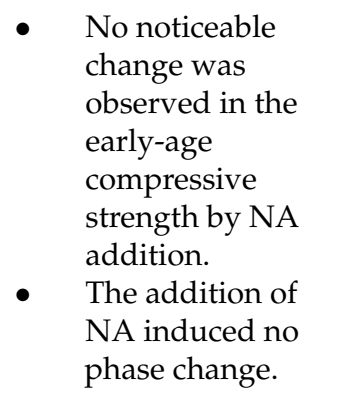 \\
\hline $\begin{array}{c}\text { Mohseni et al. } \\
\text { [77] }\end{array}$ & $\begin{array}{l}\text { Effects of NA on } \\
\text { mechanical, } \\
\text { rheological, and } \\
\text { durability } \\
\text { properties of } \\
\text { SCC }\end{array}$ & $\begin{array}{c}3,7,28 \text { and } \\
90 \text { days }\end{array}$ & $\begin{array}{c}50 \times 50 \times \\
50 \mathrm{~mm}^{3} \text { and } \\
\Phi 100 \times \\
50 \mathrm{~mm}\end{array}$ & 0.4 & NA & $15 \mathrm{~nm}$ & $1 \%, 3 \%$, and $5 \%$ & $\begin{array}{ll}\text { - } & \text { Water } \\
& \text { absorption } \\
\text { - } & \text { Electrical } \\
& \text { resistivity } \\
\text { - } & \text { Rapid chloride } \\
& \text { permeability } \\
\text { tests }\end{array}$ & $\begin{array}{l}\text { - } \quad \text { NA improved the } \\
\text { flexural and } \\
\text { compressive } \\
\text { strengths of } \\
\text { specimens with } \\
10 \% \text { and } 20 \% \\
\text { RHA. } \\
\text { The most effective } \\
\text { amount of NA } \\
\text { was } 3 \% \text { by weight } \\
\text { of the binder. } \\
\text { Water absorption } \\
\text { decreased with the } \\
\text { increase of NA } \\
\text { dosage up to } 3 \% \text {. } \\
\text { The formation of } \\
\text { denser } \\
\text { microstructure } \\
\text { with NA addition. }\end{array}$ \\
\hline
\end{tabular}


Table 4. Cont.

\begin{tabular}{|c|c|c|c|c|c|c|c|c|c|}
\hline \multirow[b]{2}{*}{ Ref. } & \multirow[b]{2}{*}{ Research Topic } & \multirow{2}{*}{$\begin{array}{c}\text { Test Age } \\
\text { (day) }\end{array}$} & \multirow[b]{2}{*}{ Sample Size } & \multirow[b]{2}{*}{ W/C (\%) } & \multicolumn{4}{|c|}{ Alumina } & \multirow[b]{2}{*}{ Remarks } \\
\hline & & & & & Type & Size $(\mathrm{mm})$ & $\begin{array}{l}\text { Amount of } \\
\text { Alumina }\end{array}$ & $\begin{array}{c}\text { Investigated } \\
\text { Parameters }\end{array}$ & \\
\hline $\begin{array}{c}\text { Heikal et al. } \\
\text { [141] }\end{array}$ & $\begin{array}{l}\text { Physico- } \\
\text { mechanical, } \\
\text { microstructure } \\
\text { characteristics } \\
\text { and fire } \\
\text { resistance of } \\
\text { cement pastes } \\
\text { with NA - }\end{array}$ & $\begin{array}{l}3,7,28, \text { and } \\
90 \text { days. }\end{array}$ & - & & NA & $15 \pm 3 \mathrm{~nm}$ & $1,2,4$ and $6 \%$ & $\begin{array}{ll}\text { - } & \text { Setting times, } \\
\text { - } & \text { Bulk density } \\
\text { - } & \text { Gel/space ratio } \\
& \text { Compressive } \\
\text { - } & \text { strength } \\
\text { - } & \text { TEM } \\
\text { - } & \text { Differential } \\
& \text { thermal analysis } \\
& \text { (DTA)/TGA } \\
\text { - } & \text { Free lime } \\
& \text { contents }(F L, \%)\end{array}$ & $\begin{array}{l}\text { NA addition } \\
\text { shortens the } \\
\text { setting times. } \\
1 \% \text { NA enhanced } \\
\text { the compressive } \\
\text { strength of the } \\
\text { pastes up to } \\
27.22 \% . \\
\text { NA speeded up } \\
\text { the hydration. } \\
\text { - } 1 \% \text { NA enhanced } \\
\text { the fire resistance. }\end{array}$ \\
\hline $\begin{array}{l}\text { Khaliq and } \\
\text { Khan [121] }\end{array}$ & $\begin{array}{l}\text { High- } \\
\text { temperature } \\
\text { material } \\
\text { properties of } \\
\text { calcium } \\
\text { aluminate } \\
\text { cement concrete }\end{array}$ & $\begin{array}{c}3,14 \text {, and } \\
28 \text { days }\end{array}$ & $\begin{array}{c}\Phi 100 \mathrm{~mm} \times \\
200 \mathrm{~mm}\end{array}$ & 0.5 & $\begin{array}{c}\text { calcium } \\
\text { aluminate } \\
\text { cement } \\
\text { concrete }\end{array}$ & - & - & $\begin{array}{ll}\text { - } & \text { SEM } \\
\text { - } & \text { Compressive } \\
& \text { and tensile } \\
& \text { strength } \\
\text { - } & \text { Elastic modulus } \\
\text { - } & \text { Compressive } \\
\text { - } & \text { toughness } \\
\text { Visual } \\
\text { investigations }\end{array}$ & 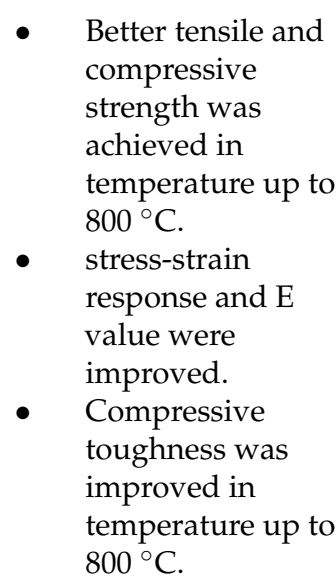 \\
\hline
\end{tabular}


Table 4. Cont.

\begin{tabular}{|c|c|c|c|c|c|c|c|c|c|}
\hline \multirow[b]{2}{*}{ Ref. } & \multirow[b]{2}{*}{ Research Topic } & \multirow{2}{*}{$\begin{array}{c}\text { Test Age } \\
\text { (day) }\end{array}$} & \multirow[b]{2}{*}{ Sample Size } & \multirow[b]{2}{*}{ W/C (\%) } & \multicolumn{4}{|c|}{ Alumina } & \multirow[b]{2}{*}{ Remarks } \\
\hline & & & & & Type & Size $(\mathrm{mm})$ & $\begin{array}{l}\text { Amount of } \\
\text { Alumina }\end{array}$ & $\begin{array}{l}\text { Investigated } \\
\text { Parameters }\end{array}$ & \\
\hline $\begin{array}{l}\text { Niewiadomski } \\
\text { et al. [42] }\end{array}$ & $\begin{array}{l}\text { Self-compacting } \\
\text { concrete } \\
\text { modified with } \\
\text { NA }\end{array}$ & $\begin{array}{l}28 \text { and } \\
90 \text { days }\end{array}$ & $\begin{array}{c}100 \times 100 \times \\
100 \mathrm{~mm}^{3} \\
40 \times 40 \times \\
160 \mathrm{~mm}^{3} \\
\text { and } \\
\Phi 25 \mathrm{~mm} \times \\
20 \mathrm{~mm}\end{array}$ & 0.42 & NA & Below $50 \mathrm{~nm}$ & $\begin{array}{c}\text { Cement } \\
\text { replacement } \\
0.5 \text { wt. } \%, 1.0 \\
\text { wt. } \%, 2.0 \text { wt. } \% \\
\text { and 3.0 wt. } \% \text { of } \\
\text { the. }\end{array}$ & $\begin{array}{ll}\text { - } & \text { Compressive } \\
\text { - } & \text { strength } \\
\text { - } & \text { hlexural strength } \\
\text { - } & \text { Elastic modulus }\end{array}$ & $\begin{array}{l}\text { The fluidity of } \\
\text { concrete } \\
\text { deteriorated with } \\
\text { an increased } \\
\text { amount of NA. } \\
\text { The samples with } \\
\text { the addition of NA } \\
\text { had a larger size of } \\
\text { air pores than the } \\
\text { reference sample. } \\
\text { Concretes with } \\
\text { NA showed no } \\
\text { improvement in } \\
\text { compressive and } \\
\text { flexural strengths. }\end{array}$ \\
\hline
\end{tabular}




\section{Conclusions}

This review is aimed to investigate the effect of NA on rheology and mechanical parameters of SCC subjected to elevated temperature. Then the potential of predicting the mechanical parameters of SCC is further studied. It was concluded from the literature review that the rheology parameters of the fresh SCC are significantly affected by the addition of NA due to their high surface-area-to-volume ratio. The addition of NA reduces slump flow diameter while the variation of the workability is contributed with the replacement ratio. NA has lower water and chloride ions permeability that is due to the accelerated hydration process. Moreover, enhanced durability and compressive strength are achieved by adding a small amount of NA to SCC. Therefore, the use of NA enhances the performance of SCC. The addition of NA to SCC results in a denser microstructure as compared to normal SCC. The authors believe that future research in the field of NA should further concentrate on enhancing the elevated temperature resistance and thermal behavior of SCC to enable more sustainable and durable construction and to extend the SCC use to more application fields.

Author Contributions: Conceptualization, H.S., and S.E.M.-Y.; methodology, H.S., S.E.M.-Y. and M.H.; software, H.S.; validation, H.S., and S.E.M.-Y.; formal analysis, H.S., S.E.M.-Y. and M.H.; investigation, H.S., and S.E.M.-Y.; resources, H.S., S.E.M.-Y., M.H., S.S.R.K., and M.P.; data curation, H.S.; writing—original draft preparation, H.S., S.E.M.-Y. and M.H.; writing—review and editing, H.S., S.E.M.-Y., M.H., M.P. and S.S.R.K.; visualization, H.S., S.E.M.-Y., M.H. S.S.R.K., and M.P.; supervision, H.S.; project administration, H.S., S.E.M.-Y. M.H., S.S.R.K., and M.P. funding acquisition H.S., S.E.M.-Y., M.H., S.S.R.K., and M.P. All authors have read and agreed to the published version of the manuscript.

Funding: The research was supported by the Islamic Azad University, Najafabad Branch, and the Ministry of Education, Youth, and Sports of the Czech Republic and the European Union (European Structural and Investment Funds Operational Program Research, Development, and Education) in the framework of the project "Modular platform for autonomous chassis of specialized electric vehicles for freight and equipment transportation", Reg. No. CZ.02.1.01/0.0/0.0/16_025/0007293.

Acknowledgments: The authors would like to acknowledge the invaluable help of N. Heidari during the preparation of this manuscript.

Conflicts of Interest: The authors declare no conflict of interest.

\section{References}

1. Shokravi, H.; Shokravi, H.; Bakhary, N.; Heidarrezaei, M.; Rahimian Koloor, S.S.; Petrů, M. Application of the subspace-based methods in health monitoring of civil structures: A Systematic review and meta-analysis. Appl. Sci. 2020, 10, 3607. [CrossRef]

2. Shokravi, H.; Shokravi, H.; Shokravi, N.; Bakhary, N.; Koloor, S.S.R.; Petrů, M. Health monitoring of civil infrastructures by subspace system identification method: An overview. Appl. Sci. 2020, 10, 2786. [CrossRef]

3. Shokravi, H.; Shokravi, H.; Shokravi, N.; Bakhary, N.; Heidarrezaei, M.; Koloor, S.R.K.; Petru, M. A review on vehicle classification methods and the potential of using smart-vehicle-assisted techniques. Sensors 2020, 20, 3274. [CrossRef] [PubMed]

4. Shokravi, H.; Shokravi, H.; Shokravi, N.; Bakhary, N.; Heidarrezaei, M.; Koloor, S.R.K.; Petru, M. Vehicle-assisted techniques for health monitoring of bridges. Sensors 2020, 20, 3460. [CrossRef] [PubMed]

5. Shokravi, H.; Shokravi, H.; Shokravi, N.; Bakhary, N.; Koloor, S.S.R.; Petrů, M. A comparative study of the data-driven stochastic subspace methods for health monitoring of structures: A bridge case study. Appl. Sci. 2020, 10, 3132. [CrossRef]

6. Shokravi, H.; Mohammadyan-Yasouj, S.E.; Rafiei, P.; Rahimian Koloor, S.S.; Petrů, M. Temperature impact on engineered cementitious composite containing basalt fibers. J. Mater. Res. Technol. 2021. (Under review).

7. Mohammadyan-Yasouj, S.E.; Ahangar, H.A.; Oskoei, N.A.; Shokravi, H.; Koloor, S.S.R.; Petrů, M. Thermal performance of alginate concrete reinforced with basalt fiber. Crystals 2020, 10, 779. [CrossRef]

8. Praveenkumar, T.R.; Vijayalakshmi, M.M.; Meddah, M.S. Strengths and durability performances of blended cement concrete with $\mathrm{TiO}_{2}$ nanoparticles and rice husk ash. Constr. Build. Mater. 2019, 217, 343-351. [CrossRef]

9. Nazari, A.; Riahi, S. Improvement compressive strength of concrete in different curing media by $\mathrm{Al}_{2} \mathrm{O}_{3}$ nanoparticles. Mater. Sci. Eng. A 2011, 528, 1183-1191. [CrossRef]

10. Khoshakhlagh, A.; Nazari, A.; Khalaj, G. Effects of $\mathrm{Fe}_{2} \mathrm{O}_{3}$ nanoparticles on water permeability and strength assessments of high strength self-compacting concrete. J. Mater. Sci. Technol. 2012, 28, 73-82. [CrossRef]

11. Karatas, M.; Benli, A.; Arslan, F. The effects of kaolin and calcined kaolin on the durability and mechanical properties of self-compacting mortars subjected to high temperatures. Constr. Build. Mater. 2020, 265, 120300. [CrossRef] 
12. Maia, L.; Neves, D. Developing a commercial self-compacting concrete without limestone filler and with volcanic aggregate materials. Procedia Struct. Integr. 2017, 5, 147-154. [CrossRef]

13. Ibrahim, M.H.W.; Hamzah, A.F.; Jamaluddin, N.; Ramadhansyah, P.J.; Fadzil, A.M. Split tensile strength on self-compacting concrete containing coal bottom ash. Procedia Soc. Behav. Sci. 2015, 195, 2280-2289.

14. Saha, P.; Debnath, P.; Thomas, P. Prediction of fresh and hardened properties of self-compacting concrete using support vector regression approach. Neural Comput. Appl. 2019, 32,1-16. [CrossRef]

15. Ramkumar, K.B.; Rajkumar, P.R.K.; Ahmmad, S.N.; Jegan, M. A review on performance of self-compacting concrete-use of mineral admixtures and steel fibres with artificial neural network application. Constr. Build. Mater. 2020, 261, 120215. [CrossRef]

16. Salami, B.A.; Rahman, S.M.; Oyehan, T.A.; Maslehuddin, M.; Al Dulaijan, S.U. Ensemble machine learning model for corrosion initiation time estimation of embedded steel reinforced self-compacting concrete. Measurement 2020, 165, 108141. [CrossRef]

17. Saafan, M.A.A.; Bait AL-Shab, T. Behavior of self-compacting concrete in simulated hot weather. ERJ. Eng. Res. J. 2020, 43, 223-230. [CrossRef]

18. Benaicha, M.; Roguiez, X.; Jalbaud, O.; Burtschell, Y.; Alaoui, A.H. New approach to determine the plastic viscosity of selfcompacting concrete. Front. Struct. Civ. Eng. 2016, 10, 198-208. [CrossRef]

19. Nazari, A.; Riahi, $\mathrm{S}$. The effects of $\mathrm{SiO}_{2}$ nanoparticles on physical and mechanical properties of high strength compacting concrete. Compos. Part B Eng. 2011, 42, 570-578. [CrossRef]

20. Joshaghani, A.; Balapour, M.; Mashhadian, M.; Ozbakkaloglu, T. Effects of nano- $\mathrm{TiO}_{2}$, nano- $\mathrm{Al}_{2} \mathrm{O}_{3}$, and nano- $\mathrm{Fe}_{2} \mathrm{O}_{3}$ on rheology, mechanical and durability properties of self-consolidating concrete (SCC): An experimental study. Constr. Build. Mater. 2020, 245. [CrossRef]

21. Nazari, A.; Riahi, S. The effects of $\mathrm{TiO}_{2}$ nanoparticles on physical, thermal and mechanical properties of concrete using ground granulated blast furnace slag as binder. Mater. Sci. Eng. A 2011, 528, 2085-2092. [CrossRef]

22. Nazari, A.; Riahi, S. The effect of $\mathrm{TiO}_{2}$ nanoparticles on water permeability and thermal and mechanical properties of high strength self-compacting concrete. Mater. Sci. Eng. A 2010, 528, 756-763. [CrossRef]

23. Faez, A.; Sayari, A.; Manie, S. Mechanical and rheological properties of self-compacting concrete containing $\mathrm{Al}_{2} \mathrm{O}_{3}$ nanoparticles and silica fume. Iran. J. Sci. Technol. Trans. Civ. Eng. 2020, 44, 1-11. [CrossRef]

24. Kaplan, G.; Demircan, R.K.; Cakmak, C.; Gultekin, A.B. Microwave curing effect on internal sulfate damage in nano alumina reinforced white cement. IOP Conf. Ser. Mater. Sci. Eng. 2019, 471, 032038. [CrossRef]

25. Meddah, M.S.; Praveenkumar, T.R.; Vijayalakshmi, M.M.; Manigandan, S.; Arunachalam, R. Mechanical and microstructural characterization of rice husk ash and $\mathrm{Al}_{2} \mathrm{O}_{3}$ nanoparticles modified cement concrete. Constr. Build. Mater. 2020, $255,119358$. [CrossRef]

26. Salemi, N.; Behfarnia, K. Effect of nano-particles on durability of fiber-reinforced concrete pavement. Constr. Build. Mater. 2013, 48, 934-941. [CrossRef]

27. Mohammadyan-Yasouj, S.E.; Heidari, N.; Shokravi, H. Influence of waste alumina powder on self-compacting concrete resistance under elevated temperature. J. Build. Eng. 2021. [CrossRef]

28. De Schutter, G.; Bartos, P.J.M.; Domone, P.; Gibbs, J. Self-Compacting Concrete; Whittles Publishing: Caithness, Scotland, 2008.

29. Tande, S.N.; Mohite, P.B. Applications of self compacting concrete. In Proceedings of the International Conference Concrete Structure, Singapore, 12 March 2007.

30. Aslani, F.; Liu, Y.; Wang, Y. The effect of NiTi shape memory alloy, polypropylene and steel fibres on the fresh and mechanical properties of self-compacting concrete. Constr. Build. Mater. 2019, 215, 644-659. [CrossRef]

31. Basu, P.; Agrawal, V.; Gupta, R.C. Permeation characteristics of self-compacting concrete containing sandstone slurry. Mater. Today Proc. 2020, 26, 1590-1593. [CrossRef]

32. Simonsson, P.; Emborg, M. Industrialized construction: Benefits using SCC in cast in-situ construction. Nord. Concr. Res. 2009, 39, 33-52.

33. Georgiadis, A.S.; Sideris, K.K.; Anagnostopoulos, N.S. Properties of SCC produced with limestone filler or viscosity modifying admixture. J. Mater. Civ. Eng. 2010, 22, 352-360. [CrossRef]

34. Bilir, T.; Kockal, N.U.; Khatib, J.M. Properties of SCC at elevated temperature. In Self-Compacting Concrete: Materials, Properties and Applications; Elsevier: Amsterdam, The Netherlands, 2020; pp. 195-218.

35. Kwon, S.H.; Shah, S.P.; Phung, Q.T.; Kim, J.H.; Lee, Y. Intrinsic model to predict formwork pressure. ACI Mater. J. $2010,107,20$.

36. Reinhardt, H.W.; Stegmaier, M. Self-consolidating concrete in fire. ACI Mater. J. 2006, 103, 130.

37. Kim, J.H.; Noemi, N.; Shah, S.P. Effect of powder materials on the rheology and formwork pressure of self-consolidating concrete. Cem. Concr. Compos. 2012, 34, 746-753. [CrossRef]

38. Omrane, M.; Kenai, S.; Kadri, E.-H.; Aït-Mokhtar, A. Performance and durability of self compacting concrete using recycled concrete aggregates and natural pozzolan. J. Clean. Prod. 2017, 165, 415-430. [CrossRef]

39. Koehler, E.P. Aggregates in Self-Consolidating Concrete. Ph.D. Thesis, University of Texas, Austin, TX, USA, 2007.

40. Skarendahl, A. Changing concrete construction through use of self-compacting concrete. In Proceedings of the First International Symposium on Design, Performance and Use of Self-Consolidating Concrete, Changsha, China, 26-28 May 2005; RILEM Publications SARL: Hunan, Kina, 2005; pp. 17-24.

41. D'Souza, B.; Yamamiya, H. Applications of smart dynamic concrete. In Proceedings of the International Symposium on Design, Performance and Use of Self-Consolidating Concrete, Kyoto, Japan, 19-21 August 2013; pp. 18-21. 
42. Niewiadomski, P.; Hoła, J.; Ćwirzeń, A. Study on properties of self-compacting concrete modified with nanoparticles. Arch. Civ. Mech. Eng. 2018, 18, 877-886. [CrossRef]

43. Hemalatha, T.; Sundar, K.R.R.; Murthy, A.R.; Iyer, N.R. Influence of mixing protocol on fresh and hardened properties of self-compacting concrete. Constr. Build. Mater. 2015, 98, 119-127. [CrossRef]

44. Pai, B.H.V.; Nandy, M.; Krishnamoorthy, A.; Sarkar, P.K.; George, P. Comparative study of self compacting concrete mixes containing fly ash and rice husk ash. Am. J. Eng. Res. 2014, 3, 150-154.

45. Dolatabad, Y.A.; Kamgar, R.; Nezad, I.G. Rheological and mechanical properties, acid resistance and water penetrability of lightweight self-compacting concrete containing nano- $\mathrm{SiO}_{2}$, nano- $\mathrm{TiO}_{2}$ and nano- $\mathrm{Al}_{2} \mathrm{O}_{3}$. Iran. J. Sci. Technol. Trans. Civ. Eng. 2019, $44,1-16$.

46. Sumesh, M.; Alengaram, U.J.; Jumaat, M.Z.; Mo, K.H.; Alnahhal, M.F. Incorporation of nano-materials in cement composite and geopolymer based paste and mortar-A review. Constr. Build. Mater. 2017, 148, 62-84. [CrossRef]

47. Arefi, M.R.; Rezaei-Zarchi, S. Synthesis of zinc oxide nanoparticles and their effect on the compressive strength and setting time of self-compacted concrete paste as cementitious composites. Int. J. Mol. Sci. 2012, 13, 4340-4350. [CrossRef] [PubMed]

48. Nazari, A.; Riahi, S. The effects of $\mathrm{Cr}_{2} \mathrm{O}_{3}$ nanoparticles on strength assessments and water permeability of concrete in different curing media. Mater. Sci. Eng. A 2011, 528, 1173-1182. [CrossRef]

49. Lin, K.L.; Chang, W.C.; Lin, D.F.; Luo, H.L.; Tsai, M.C. Effects of nano-SiO 2 and different ash particle sizes on sludge ash-cement mortar. J. Environ. Manag. 2008, 88, 708-714. [CrossRef] [PubMed]

50. Qing, Y.; Zenan, Z.; Deyu, K.; Rongshen, C. Influence of nano-SiO $\mathrm{S}_{2}$ addition on properties of hardened cement paste as compared with silica fume. Constr. Build. Mater. 2007, 21, 539-545. [CrossRef]

51. Nazari, A.; Riahi, S. Microstructural, thermal, physical and mechanical behavior of the self compacting concrete containing $\mathrm{SiO}_{2}$ nanoparticles. Mater. Sci. Eng. A 2010, 527, 7663-7672. [CrossRef]

52. Abhilash, P.P.; Nayak, D.K.; Sangoju, B.; Kumar, R.; Kumar, V. Effect of nano-silica in concrete; a review. Constr. Build. Mater. 2021, $278,122347$.

53. Kooshafar, M.; Madani, H. An investigation on the influence of nano silica morphology on the characteristics of cement composites. J. Build. Eng. 2020, 30, 101293. [CrossRef]

54. Orakzai, M.A. Hybrid effect of nano-alumina and nano-titanium dioxide on mechanical properties of concrete. Case Stud. Constr. Mater. 2021, 14, e00483.

55. Wang, X.; Dong, S.; Ashour, A.; Zhang, W.; Han, B. Effect and mechanisms of nanomaterials on interface between aggregates and cement mortars. Constr. Build. Mater. 2020, 240, 117942. [CrossRef]

56. Shao, Q.; Zheng, K.; Zhou, X.; Zhou, J.; Zeng, X. Enhancement of nano-alumina on long-term strength of Portland cement and the relation to its influences on compositional and microstructural aspects. Cem. Concr. Compos. 2019, 98, 39-48. [CrossRef]

57. Zhang, A.; Yang, W.; Ge, Y.; Du, Y.; Liu, P. Effects of nano-SiO 2 and nano- $\mathrm{Al}_{2} \mathrm{O}_{3}$ on mechanical and durability properties of cement-based materials: A comparative study. J. Build. Eng. 2020, 34, 101936. [CrossRef]

58. Nazari, A.; Riahi, S. The effects of zinc dioxide nanoparticles on flexural strength of self-compacting concrete. Compos. Part B Eng. 2011, 42, 167-175. [CrossRef]

59. Yang, J.; Mohseni, E.; Behforouz, B.; Khotbehsara, M.M. An experimental investigation into the effects of $\mathrm{Cr}_{2} \mathrm{O}_{3}$ and $\mathrm{ZnO}_{2}$ nanoparticles on the mechanical properties and durability of self-compacting mortar. Int. J. Mater. Res. 2015, 106, 886-892. [CrossRef]

60. Heikal, M.; Zaki, M.E.A.; Ibrahim, S.M. Characterization, hydration, durability of nano- $\mathrm{Fe}_{2} \mathrm{O}_{3}$-composite cements subjected to sulphates and chlorides media. Constr. Build. Mater. 2021, 269, 121310. [CrossRef]

61. Madandoust, R.; Mohseni, E.; Mousavi, S.Y.; Namnevis, M. An experimental investigation on the durability of self-compacting mortar containing nano- $\mathrm{SiO}_{2}$, nano- $\mathrm{Fe}_{2} \mathrm{O}_{3}$ and nano-CuO. Constr. Build. Mater. 2015, 86, 44-50. [CrossRef]

62. Khotbehsara, M.M.; Miyandehi, B.M.; Naseri, F.; Ozbakkaloglu, T.; Jafari, F.; Mohseni, E. Effect of $\mathrm{SnO}_{2}, \mathrm{ZrO}_{2}$, and CaCO 3 nanoparticles on water transport and durability properties of self-compacting mortar containing fly ash: Experimental observations and ANFIS predictions. Constr. Build. Mater. 2018, 158, 823-834. [CrossRef]

63. Massa, M.A.; Covarrubias, C.; Bittner, M.; Fuentevilla, I.A.; Capetillo, P.; Von Marttens, A.; Carvajal, J.C. Synthesis of new antibacterial composite coating for titanium based on highly ordered nanoporous silica and silver nanoparticles. Mater. Sci. Eng. C 2014, 45, 146-153. [CrossRef] [PubMed]

64. Morsy, M.S.; Alsayed, S.H.; Aqel, M. Hybrid effect of carbon nanotube and nano-clay on physico-mechanical properties of cement mortar. Constr. Build. Mater. 2011, 25, 145-149. [CrossRef]

65. Felekoğlu, B.; Sarıkahya, H. Effect of chemical structure of polycarboxylate-based superplasticizers on workability retention of self-compacting concrete. Constr. Build. Mater. 2008, 22, 1972-1980. [CrossRef]

66. Nazari, A.; Riahi, S. Effects of $\mathrm{Cr}_{2} \mathrm{O}_{3}$ nanoparticles on properties of SCC with GGBFS binder. Mag. Concr. Res. 2012, 64, 433-444. [CrossRef]

67. Bankir, M.B.; Ozturk, M.; Sevim, U.K.; Depci, T. Effect of n-CaCO 3 on fresh, hardened properties and acid resistance of granulated blast furnace slag added mortar. J. Build. Eng. 2020, 29, 101209. [CrossRef]

68. Tawfik, T.A.; Aly Metwally, K.; EL-Beshlawy, S.A.; Al Saffar, D.M.; Tayeh, B.A.; Soltan Hassan, H. Exploitation of the nanowaste ceramic incorporated with nano silica to improve concrete properties. J. King Saud Univ. Eng. Sci. 2020. [CrossRef] 
69. Jalal, M.; Ramezanianpour, A.A.; Pool, M.K. Split tensile strength of binary blended self compacting concrete containing low volume fly ash and $\mathrm{TiO}_{2}$ nanoparticles. Compos. Part B Eng. 2013, 55, 324-337. [CrossRef]

70. Quercia, G.; Spiesz, P.; Hüsken, G.; Brouwers, H.J.H. SCC modification by use of amorphous nano-silica. Cem. Concr. Compos. 2014, 45, 69-81. [CrossRef]

71. Beigi, M.H.; Berenjian, J.; Omran, O.L.; Nik, A.S.; Nikbin, I.M. An experimental survey on combined effects of fibers and nanosilica on the mechanical, rheological, and durability properties of self-compacting concrete. Mater. Des. 2013, 50, 1019-1029. [CrossRef]

72. Vassaux, S.; Gaudefroy, V.; Boulangé, L.; Pévère, A.; Mouillet, V.; Barragan-Montero, V. Towards a better understanding of wetting regimes at the interface asphalt/aggregate during warm-mix process of asphalt mixtures. Constr. Build. Mater. 2017, 133, 182-195. [CrossRef]

73. Feng, D.; Xie, N.; Gong, C.; Leng, Z.; Xiao, H.; Li, H.; Shi, X. Portland cement paste modified by TiO 2 nanoparticles: A microstructure perspective. Ind. Eng. Chem. Res. 2013, 52, 11575-11582. [CrossRef]

74. Chen, J.; Kou, S.; Poon, C. Hydration and properties of nano- $\mathrm{TiO}_{2}$ blended cement composites. Cem. Concr. Compos. 2012, 34, 642-649. [CrossRef]

75. Oltulu, M.; Şahin, R. Single and combined effects of nano- $\mathrm{SiO}_{2}$, nano- $\mathrm{Al}_{2} \mathrm{O}_{3}$ and nano- $\mathrm{Fe}_{2} \mathrm{O}_{3}$ powders on compressive strength and capillary permeability of cement mortar containing silica fume. Mater. Sci. Eng. A 2011, 528, 7012-7019. [CrossRef]

76. Mohseni, E.; Naseri, F.; Amjadi, R.; Khotbehsara, M.M.; Ranjbar, M.M. Microstructure and durability properties of cement mortars containing nano-TiO ${ }_{2}$ and rice husk ash. Constr. Build. Mater. 2016, 114, 656-664. [CrossRef]

77. Mohseni, E.; Miyandehi, B.M.; Yang, J.; Yazdi, M.A. Single and combined effects of nano-SiO ${ }_{2}$, nano- $\mathrm{Al}_{2} \mathrm{O}_{3}$ and nano-TiO ${ }_{2}$ on the mechanical, rheological and durability properties of self-compacting mortar containing fly ash. Constr. Build. Mater. 2015, 84, 331-340. [CrossRef]

78. Said, S.; Mikhail, S.; Riad, M. Recent processes for the production of alumina nano-particles. Mater. Sci. Energy Technol. 2020, 3 , 344-363. [CrossRef]

79. De Dios, A.S.; Díaz-García, M.E. Multifunctional nanoparticles: Analytical prospects. Anal. Chim. Acta 2010, 666, 1-22. [CrossRef]

80. Neouze, M.-A.; Schubert, U. Surface modification and functionalization of metal and metal oxide nanoparticles by organic ligands. Monatshefte Chem. Chem. Mon. 2008, 139, 183-195. [CrossRef]

81. Xue, Y.; Yu, W.; Mei, J.; Jiang, W.; Lv, X. A clean process for alumina extraction and ferrosilicon alloy preparation from coal fly ash via vacuum thermal reduction. J. Clean. Prod. 2019, 240, 118262. [CrossRef]

82. Bertolino, L.C.; Rossi, A.M.; Scorzelli, R.B.; Torem, M.L. Influence of iron on kaolin whiteness: An electron paramagnetic resonance study. Appl. Clay Sci. 2010, 49, 170-175. [CrossRef]

83. Murray, H.H. Structure and composition of the clay minerals and their physical and chemical properties. Dev. Clay Sci. 2006, 2, 7-31.

84. Lin, H.Y.; Wan, L.; Yang, Y.F. Aluminium hydroxide ultrafine powder extracted from fly ash. Adv. Mater. Res. 2012, 512, 1548-1553. [CrossRef]

85. Li, H.; Hui, J.; Wang, C.; Bao, W.; Sun, Z. Extraction of alumina from coal fly ash by mixed-alkaline hydrothermal method. Hydrometallurgy 2014, 147, 183-187. [CrossRef]

86. Ding, J.; Ma, S.; Shen, S.; Xie, Z.; Zheng, S.; Zhang, Y. Research and industrialization progress of recovering alumina from fly ash: A concise review. Waste Manag. 2017, 60, 375-387. [CrossRef]

87. Szente, R.N.; Schroeter, R.A.; Garcia, M.G.; Bender, O.W. Recovering aluminum via plasma processing. JOM 1997, 49, 52-55. [CrossRef]

88. Saravanakumar, R.; Ramachandran, K.; Laly, L.G.; Ananthapadmanabhan, P.V.; Yugeswaran, S. Plasma assisted synthesis of $\gamma$-alumina from waste aluminium dross. Waste Manag. 2018, 77, 565-575. [CrossRef]

89. Kumar, P.M.; Balasubramanian, C.; Sali, N.D.; Bhoraskar, S.V.; Rohatgi, V.K.; Badrinarayanan, S. Nanophase alumina synthesis in thermal arc plasma and characterization: Correlation to gas-phase studies. Mater. Sci. Eng. B 1999, 63, 215-227. [CrossRef]

90. Kumar, P.M.; Borse, P.; Rohatgi, V.K.; Bhoraskar, S.V.; Singh, P.; Sastry, M. Synthesis and structural characterization of nanocrystalline aluminium oxide. Mater. Chem. Phys. 1994, 36, 354-358. [CrossRef]

91. Fu, L.; Johnson, D.L.; Zheng, J.G.; Dravid, V.P. Microwave plasma synthesis of nanostructured $\gamma-\mathrm{Al}_{2} \mathrm{O}_{3}$ powders. J. Am. Ceram. Soc. 2003, 86, 1635-1637. [CrossRef]

92. Stanislaus, A.; Al-Dolama, K.; Absi-Halabi, M. Preparation of a large pore alumina-based HDM catalyst by hydrothermal treatment and studies on pore enlargement mechanism. J. Mol. Catal. A Chem. 2002, 181, 33-39. [CrossRef]

93. Akia, M.; Alavi, S.M.; Rezaei, M.; Yan, Z.-F. Optimizing the sol-gel parameters on the synthesis of mesostructure nanocrystalline $\gamma-\mathrm{Al}_{2} \mathrm{O}_{3}$. Microporous Mesoporous Mater. 2009, 122, 72-78. [CrossRef]

94. Weitkamp, J.; Sing, K.S.W.; Schüth, F. Handbook of Porous Solids; Wiley: Hoboken, NJ, USA, 2002.

95. Mirjalili, F.; Hasmaliza, M.; Abdullah, L.C. Size-controlled synthesis of nano $\alpha$-alumina particles through the sol-gel method. Ceram. Int. 2010, 36, 1253-1257. [CrossRef]

96. Belekar, R.M.; Dhoble, S.J. Activated alumina granules with nanoscale porosity for water defluoridation. Nano Struct. Nano Objects 2018, 16, 322-328. [CrossRef]

97. Esmaeilirad, M.; Zabihi, M.; Shayegan, J.; Khorasheh, F. Oxidation of toluene in humid air by metal oxides supported on $\gamma$-alumina. J. Hazard. Mater. 2017, 333, 293-307. [CrossRef] 
98. Feng, G.; Jiang, F.; Jiang, W.; Liu, J.; Zhang, Q.; Hu, Q.; Miao, L.; Wu, Q. Effect of oxygen donor alcohol on nonaqueous precipitation synthesis of alumina powders. Ceram. Int. 2019, 45, 354-360. [CrossRef]

99. Hong, J.-P.; Jun, W.; Chen, H.-Y.; Sun, B.-D.; Li, J.-J.; Chong, C. Process of aluminum dross recycling and life cycle assessment for Al-Si alloys and brown fused alumina. Trans. Nonferrous Met. Soc. China 2010, 20, 2155-2161. [CrossRef]

100. Calder, G.V.; Stark, T.D. Aluminum reactions and problems in municipal solid waste landfills. Pract. Period. Hazardous Toxic Radioact. Waste Manag. 2010, 14, 258-265. [CrossRef]

101. EI Katatny, E.A.; Halawy, S.A.; Mohamed, M.A.; Zaki, M.I. Recovery of high surface area alumina from aluminium dross tailings. J. Chem. Technol. Biotechnol. Int. Res. Process. Environ. Clean Technol. 2000, 75, 394-402. [CrossRef]

102. David, E.; Kopac, J. Aluminum recovery as a product with high added value using aluminum hazardous waste. J. Hazard. Mater. 2013, 261, 316-324. [CrossRef]

103. Dash, B.; Das, B.R.; Tripathy, B.C.; Bhattacharya, I.N.; Das, S.C. Acid dissolution of alumina from waste aluminium dross. Hydrometallurgy 2008, 92, 48-53. [CrossRef]

104. Das, J.; Patra, B.S.; Baliarsingh, N.; Parida, K.M. Adsorption of phosphate by layered double hydroxides in aqueous solutions. Appl. Clay Sci. 2006, 32, 252-260. [CrossRef]

105. Sarker, M.S.R.; Alam, M.Z.; Qadir, M.R.; Gafur, M.A.; Moniruzzaman, M. Extraction and characterization of alumina nanopowders from aluminum dross by acid dissolution process. Int. J. Miner. Metall. Mater. 2015, 22, 429-436. [CrossRef]

106. Singh, U.; Ansari, M.S.; Puttewar, S.P.; Agnihotri, A. Studies on process for conversion of waste aluminium dross into value added products. Russ. J. Non Ferrous Met. 2016, 57, 296-300. [CrossRef]

107. How, L.F.; Islam, A.; Jaafar, M.S.; Taufiq-Yap, Y.H. Extraction and characterization of $\Gamma$-alumina from waste aluminium dross. Waste Biomass Valoriz. 2017, 8, 321-327. [CrossRef]

108. Yang, S.-F.; Wang, T.-M.; Shie, Z.-Y.J.; Jiang, S.-J.; Hwang, C.-S.; Tzeng, C.-C. Fine $\mathrm{Al}_{2} \mathrm{O}_{3}$ powder produced by radio-frequency plasma from aluminum dross. IEEE Trans. Plasma Sci. 2014, 42, 3751-3755. [CrossRef]

109. Ashish, D.K.; Verma, S.K. Robustness of self-compacting concrete containing waste foundry sand and metakaolin: A sustainable approach. J. Hazard. Mater. 2020, 401, 123329. [CrossRef]

110. Vali, R.H.; Wani, M.M. The effect of mixed nano-additives on performance and emission characteristics of a diesel engine fuelled with diesel-ethanol blend. Mater. Today Proc. 2021. [CrossRef]

111. Uysal, M. Self-compacting concrete incorporating filler additives: Performance at high temperatures. Constr. Build. Mater. 2012, 26, 701-706. [CrossRef]

112. Zhu, W.; Gibbs, J.C. Use of different limestone and chalk powders in self-compacting concrete. Cem. Concr. Res. 2005, 35, 1457-1462. [CrossRef]

113. Uysal, M.; Sumer, M. Performance of self-compacting concrete containing different mineral admixtures. Constr. Build. Mater. 2011, 25, 4112-4120. [CrossRef]

114. Fathi, H.; Lameie, T.; Maleki, M.; Yazdani, R. Simultaneous effects of fiber and glass on the mechanical properties of selfcompacting concrete. Constr. Build. Mater. 2017, 133, 443-449. [CrossRef]

115. Ahmad, S.; Umar, A.; Masood, A. Properties of normal concrete, self-compacting concrete and glass fibre-reinforced selfcompacting concrete: An experimental study. Procedia Eng. 2017, 173, 807-813. [CrossRef]

116. Anand, N.; Arulraj, G.P. The effect of elevated temperature on concrete materials-A literature review. Int. J. Civ. Struct. Eng. 2011, 1, 928-938.

117. Annerel, E.; Taerwe, L.; Vandevelde, P. Assessment of temperature increase and residual strength of SCC after fire exposure. In Proceedings of the 5th International RILEM Symposium on Self-Compacting Concrete, Ghent, Belgium, 5-7 September 2007; pp. 715-720.

118. Pineaud, A.; Pimienta, P.; Rémond, S.; Carré, H. Mechanical properties of high performance self-compacting concretes at room and high temperature. Constr. Build. Mater. 2016, 112, 747-755. [CrossRef]

119. Andiç-Çakır, Ö.; Hızal, S. Influence of elevated temperatures on the mechanical properties and microstructure of self consolidating lightweight aggregate concrete. Constr. Build. Mater. 2012, 34, 575-583. [CrossRef]

120. Ma, Q.; Guo, R.; Zhao, Z.; Lin, Z.; He, K. Mechanical properties of concrete at high temperature-A review. Constr. Build. Mater. 2015, 93, 371-383. [CrossRef]

121. Khaliq, W.; Khan, H.A. High temperature material properties of calcium aluminate cement concrete. Constr. Build. Mater. 2015, 94, 475-487. [CrossRef]

122. Lea, F.C. The resistance to fire of concrete and reinforced concrete. J. Soc. Chem. Ind. 1922, 41, 395R-396R. [CrossRef]

123. Qadir, S.S. Strength and behavior of self compacting concrete with crushed ceramic tiles as partial replacement for coarse aggregate and subjected to elevated temperature. Int. J. Eng. Technol. Manag. Appl. Sci. 2015, 3, 278-286.

124. Norhasri, M.S.M.; Hamidah, M.S.; Fadzil, A.M. Applications of using nano material in concrete: A review. Constr. Build. Mater. 2017, 133, 91-97. [CrossRef]

125. Ashoor, M.; Khorshidi, A.; Sarkhosh, L. Appraisal of new density coefficient on integrated-nanoparticles concrete in nuclear protection. Kerntechnik 2020, 85, 9-14. [CrossRef]

126. Mousavi, S.S.; Mousavi Ajarostaghi, S.S.; Bhojaraju, C. A critical review of the effect of concrete composition on rebar-concrete interface (RCI) bond strength: A case study of nanoparticles. SN Appl. Sci. 2020, 2, 1-23. [CrossRef] 
127. Niewiadomski, P.; Stefaniuk, D. Creep assessment of the cement matrix of self-compacting concrete modified with the addition of nanoparticles using the indentation method. Appl. Sci. 2020, 10, 2442. [CrossRef]

128. Xu, S.Y.; Zhang, Y.M.; Pan, L.S.; Tan, W. Research on characterization and chemical composition of baoluo kaolin in hainan province. Adv. Mater. Res. Trans Tech Publ. 2011, 233, 2258-2262. [CrossRef]

129. Gowda, R.; Narendra, H.; Nagabushan, B.M.; Rangappa, D.; Prabhakara, R. Investigation of nano-alumina on the effect of durability and micro-structural properties of the cement mortar. Mater. Today Proc. 2017, 4, 12191-12197. [CrossRef]

130. Rasin, F.A.; Abbas, L.K.; Kadhim, M.J. Study the effects of nano-materials addition on some mechanical properties of cement mortar. Eng. Technol. J. 2017, 35, 348-355.

131. Liu, F.; Zhang, T.; Luo, T.; Zhou, M.; Ma, W.; Zhang, K. The effects of Nano-SiO 2 and $\mathrm{Nano}^{-\mathrm{TiO}} 2$ addition on the durability and deterioration of concrete subject to freezing and thawing cycles. Materials 2019, 12, 3608. [CrossRef] [PubMed]

132. Al-Luhybi, A.S.; Altalabani, D. The Influence of Nano-Silica on the Properties and Microstructure of Lightweight Concrete: A Review. IOP Conf. Ser. Mater. Sci. Eng. 2021, 1094, 012075. [CrossRef]

133. Mukhopadhyay, S.C.; Ihara, I. Sensors and technologies for structural health monitoring: A review. New Dev. Sens. Technol. Struct. Heal. Monit. 2011, 96, 1-14.

134. Sua-iam, G.; Makul, N. Rheological and mechanical properties of cement-fly ash self-consolidating concrete incorporating high volumes of alumina-based material as fine aggregate. Constr. Build. Mater. 2015, 95, 736-747. [CrossRef]

135. Farzadnia, N.; Abang Ali, A.A.; Demirboga, R. Characterization of high strength mortars with nano alumina at elevated temperatures. Cem. Concr. Res. 2013, 54, 43-54. [CrossRef]

136. Behfarnia, K.; Salemi, N. The effects of nano-silica and nano-alumina on frost resistance of normal concrete. Constr. Build. Mater. 2013, 48, 580-584. [CrossRef]

137. Zhan, B.J.; Xuan, D.X.; Poon, C.S. The effect of nanoalumina on early hydration and mechanical properties of cement pastes. Constr. Build. Mater. 2019, 202, 169-176. [CrossRef]

138. Szymanowski, J.; Sadowski, L. The development of nanoalumina-based cement mortars for overlay applications in concrete floors. Materials 2019, 12, 3465. [CrossRef] [PubMed]

139. Li, Z.; Wang, H.; He, S.; Lu, Y.; Wang, M. Investigations on the preparation and mechanical properties of the nano-alumina reinforced cement composite. Mater. Lett. 2006, 60, 356-359. [CrossRef]

140. Barbhuiya, S.; Mukherjee, S.; Nikraz, H. Effects of nano- $\mathrm{Al}_{2} \mathrm{O}_{3}$ on early-age microstructural properties of cement paste. Constr. Build. Mater. 2014, 52, 189-193. [CrossRef]

141. Heikal, M.; Ismail, M.N.; Ibrahim, N.S. Physico-mechanical, microstructure characteristics and fire resistance of cement pastes containing $\mathrm{Al}_{2} \mathrm{O}_{3}$ nano-particles. Constr. Build. Mater. 2015, 91, 232-242. [CrossRef]

142. Sua-iam, G.; Makul, N. Use of recycled alumina as fine aggregate replacement in self-compacting concrete. Constr. Build. Mater. 2013, 47, 701-710. [CrossRef]

143. Mohseni, E.; Khotbehsara, M.M.; Naseri, F.; Monazami, M.; Sarker, P. Polypropylene fiber reinforced cement mortars containing rice husk ash and nano-alumina. Constr. Build. Mater. 2016, 111, 429-439. [CrossRef] 